\title{
THE ROYAL SITE OF SAN LORENZO DE EL ESCORIAL PROBLEMS, AREAS OF IMPROVEMENT AND SUSTAINABLE TOURISM DEVELOPMENT (PART 1)
}

\section{DESCRIPTION}

\section{A. Brief history of the Royal Site of San Lorenzo de EI Escorial}

Located on one of the slopes of Mount Abantos ${ }^{1}$, inserted in an area of great environmental value and very close to the Sierra de Guadarrama National Park ${ }^{2}$, in 1562 this place was chosen by Philip II of Spain (1527-1598) for the construction of the Monastery of San Lorenzo de El Escorial in commemoration of the victory achieved in Saint Quentin on August 10, 1557, against the troops of Henry II of France (1519-1559). The project of the Monastery was commissioned to Juan Bautista de Toledo in 1559 and developed by Juan de Herrera, who completed the project in 1584 creating an architectural style characterized by its sobriety and purity of lines, the Herrerian.

At the end of the sixteenth century, the palatial-monastic complex and its closest surroundings were the subject of several reorderings that lasted during the following century due to the urban and population growth that occurred north of the Monastery. In the eighteenth century, under a new royal dynasty, the Bourbons, and more specifically during the reign of Charles III (1716-1788), the Monastery recovered part of its previous importance as a center of power. Due to constant complaints and demands for housing by royal officials, on May 3, 1767, Charles III authorized the construction of several buildings around the Monastery.

The following year began an urbanization plan that would not conclude until 1785 , directed by Juan de Villanueva. It was intended to provide the environment near the

\footnotetext{
${ }^{1}$ It is one of the most outstanding mountains of the Sierra de Guadarrama (Central System), with a height of 1753 meters. It currently enjoys special protection due to its inclusion by the Community of Madrid as an Asset of Cultural Interest (BIC) by Decree 52/2006, of June 15 (https://www.iberley.es/legislacion/decreto-52-2006-15-junio-declara-bien-interes-culturalcategoriaterritorio-historico-real-sitio-san-lorenzo-escorial-constituido-ambito-delimitado-historicafelipe-ii-3781795).

2 Declared as such by Law 7/2013, of 25 June. It has a protected area of 30,000 hectares comprising part of the western territory of the Community of Madrid and the south of Castilla-León (province of Segovia). It is the most recently created National Park and the fourth in extension. According to statistical data provided by the Statistical Yearbook of Spain in 2017, it was the second most visited (2.989556 visitors) after the Teide National Park. For more information, see Law 7/2013, of June 25, declaration of the Sierra de Guadarrama National Park (https://www.boe.es/buscar/doc.php?id=BOE-A-2013-6900) and Statistical Yearbook of Spain 2017 (https://www.ine.es/prodyser/pubweb/anuario17/anu17_01entor.pdf).
} 
Lonja, with buildings according to the category of a Royal Site, respecting the demarcation made in the time of Philip II. These new buildings include the Consul's House or the Royal Colosseum, and the Casitas del Príncipe y del Infante. In 1820, and as a result of the confiscation process during the Liberal Triennium (1820-1823), almost all the farms belonging to the Monastery (except the place of La Herrería and the aforementioned Casitas) became private property, a fact that endowed the municipality of San Lorenzo with its current territorial configuration.

In the twentieth century, and until the beginning of the Civil War (1936-1939) visits to the municipality and its historical-artistic assets were made, mainly, by members of the Madrid bourgeoisie who spent their summer holidays in it or in nearby towns. Until the promulgation of the Heritage Law of 1932, of March $22^{3}$, by the government of the Second Republic, which allowed free access for all citizens, visits to the Monastery and other heritage sites of historical-artistic interest, could only be made under prior authorization, which used to be granted only to distinguished personalities from the more affluent classes. During the 1940s and 1950s, the greater access of the wealthiest population to private means of transport, allowed several municipalities in the Madrid mountains, including San Lorenzo de El Escorial, to become important places to spend the summer holidays.

Since the last decades of the last century, the Real Sitio de San Lorenzo de El Escorial has become one of the most outstanding tourist destinations in the Community of Madrid thanks to the richness of its heritage. The national and international recognition of the Royal Site as a place of special interest, can be seen, among others, with the consideration in 1971 as a Historic Artistic Site by Decree 1857/1971, of July $8^{4}$, and especially as a World Heritage Site by UNESCO in $1984^{5}$. More recently through Decree 52/2006, of June $15^{6}$, the Community of Madrid granted it the consideration of Historical Territory.

\footnotetext{
${ }^{3}$ https://www.boe.es/datos/pdfs/BOE/1932/084/A02067-02069.pdf

${ }^{4}$ https://www.boe.es/diario_boe/txt.php?id=BOE-A-1971-43675

${ }^{5}$ https://web.archive.org/web/20091107191045/http://www.mcu.es/patrimonio/MC/PME/BienesDec/L istadoBienes/Escorial.html

${ }^{6}$ https://www.iberley.es/legislacion/decreto-52-2006-15-junio-declara-bien-interes-culturalcategoriaterritorio-historico-real-sitio-san-lorenzo-escorial-constituido-ambito-delimitado-historicafelipe-ii- 3781795
} 


\section{B. The municipality of San Lorenzo de El Escorial}

Located about 48 kilometers from Madrid capital, in the foothills of the Sierra de Guadarrama and extending along the southern slope of Mount Abantos, San Lorenzo de El Escorial has, in addition to its outstanding historical heritage, a natural environment of great ecological value that has received various recognitions that give it special protection $^{7}$. The average altitude of the municipality is 1032 meters, and its term covers an area of 56, $4 \mathrm{~km}^{2}$ that runs along the southern slope of Mount Abantos and the north of Las Machotas, continuing north to Cuelgamuros (where the Valley of the Fallen is located) and the neighboring town of Guadarrama. To the southwest it borders the municipality of El Escorial through the Casita del Príncipe.

According to the data provided by the National Institute of Statistics (INE), in 2018, San Lorenzo de El Escorial had a population of 18,088 inhabitants ${ }^{8}$ that, especially in holiday periods and weekends, increases significantly due to second homes located both in the urban core and in nearby urbanizations.

With regard to its economy, the most important sector of the municipality is tourism and, to a lesser extent, hospitality and commerce (the latter especially diminished after the financial crisis of 2007-2008) $)^{9,10}$.

\section{The Royal Site of San Lorenzo de El Escorial as a tourist destination: situation, problems to be solved and action measures}

Although it is one of the most important tourist destinations in the Community of Madrid, thanks to its remarkable historical, environmental and cultural heritage ${ }^{11,12}$, unfortunately

\footnotetext{
${ }^{7}$ Both the Pinar de Abantos and La Herrería were declared by Decree 2418/1961, of November 16, as a Picturesque Place (https://www.boe.es/diario_boe/txt.php?id=BOE-A-1961-22493). It also has the qualification LIC ES 3110005 "Guadarrama River Basin" within the Natura 2000 Network (http://www.madrid.org/es/transparencia/informacion-institutional/plans-programs/plangestion-zonaespecial-conservacion-es3110005-cuenca)

${ }^{8}$ https://www.ine.es/nomen2/index.do

${ }^{9}$ https://aquienlasierra.es/san-lorenzo-de-el-escorial/cartas-de-los-lectores-el-ocaso-de-la callepozas/39993/

${ }^{10}$ https://www.vecinos.eu/revitalizamos-el-comercio-de-san-lorenzo/

${ }^{11}$ San Lorenzo de El Escorial has two of the places managed by National Heritage that receive the highest number of visitors annually after the Royal Palace of Madrid (1,552,481 in 2018) It is the Monastery of San Lorenzo de El Escorial (504,004 people in 2018) (https://www.madridesnoticia.es/2019/01/palacioreal-madrid-mas-visitado-espana-2018/) and the Valley of the Fallen $(378,875$ in 2018) (https://elpais.com/cultura/2019/01/03/actualidad/1546533314_068761.html).

12 In addition to the different musical and dramaturrgical shows that take place in the Real Coliseo de Carlos III (http://www.comunidad.madrid/centros/real-coliseo-carlos-iii-san-lorenzo-escorial) and the Teatro Auditorio de San Lorenzo de El Escorial (comunidad.madrid/centros/teatro-auditorio-san-
} 
the municipality does not benefit it as much as it should from the tourist activity due to a series of factors that will be briefly exposed.

- first of all, its proximity to a large city such as Madrid and the good communications ${ }^{13}$ that the town has have turned San Lorenzo de El Escorial into a destination of mere transit to other nuclei that also have an important historical heritage, such as the cities of Ávila $(70 \mathrm{~km})$ and Segovia $(54 \mathrm{~km})$, or hikers from other parts of the Community of Madrid and neighboring provinces who return to their places of origin on the same day. This causes that the stay of visitors is limited to a few hours, so both spending and overnight stays in the town are scarce (despite having an acceptable hotel offer ${ }^{14}$ ), even during the celebration of the Summer Courses of the Complutense University of Madrid $^{15}$ in the Euroforum ${ }^{16}$, expressly built to promote San Lorenzo de El Escorial as a place of celebration of various events, meetings and congresses.

- the excessive tourist pressure that supports a certain area of the municipality, specifically the one that includes the whole of the Monastery, the Lonja, Floridablanca, del Rey and Duque de Alba streets, as well as the surroundings of the Plaza de la Constitución ${ }^{17}$. In contrast, the rest of the streets and places of interest that the population also has are completely unknown to visitors despite the fact that the City Council has launched several initiatives such as, for example, two urban routes that aim to publicize other areas of the town ${ }^{18}$ and unload part of that agglomeration of visitors, although with little success. Although the pedestrianization of Juan de Leyva Street was undertaken to transform it into a tourist street and thus decongest Juan de Toledo Street through its inclusion in

\footnotetext{
lorenzoescorial), highlights the Pilgrimage of Our Lady of the Virgin of Grace (held on the second Sunday of September) and the traditional monumental Belén (https://todosobremadrid.com/que-hacer/belendesan-lorenzo-de-el-escorial/)

${ }^{13}$ San Lorenzo de El Escorial has 14 bus lines (urban and interurban) operated by the company Autobuses Herranz. Lines 661 and 664 connect the town with Madrid (and vice versa) to the Moncloa Interchange (dock 11) in just over 45 minutes. Also, the neighboring municipality of El Escorial has a RENFE Cercanías station that, in addition to Madrid (the journey takes approximately $1 \mathrm{~h}$ and 8 minutes), connects both municipalities with the city of Ávila (lines C3a and C8).

${ }^{14}$ According to data from the Institute of Statistics of the Community of Madrid, in 2018 the municipality had 624 hotel beds (see annex figure 2)

${ }^{15} \mathrm{https} / / / \mathrm{www} . \mathrm{ucm} . \mathrm{es} / \mathrm{cursos}$ deverano/programacion

${ }^{16}$ https://www.euroforum.es/

${ }^{17}$ See in annexes Figure 1

${ }^{18}$ (https://sanlorenzoturismo.es/es/ruta-por-el-siglo-xvi) y (https://sanlorenzoturismo.es/es/ruta-porelsiglo-xviii)
} 
urban routes designed by the consistory, reality has shown (and shows) that visitors continue to limit their visit to the Monastery and its closest environment, where most restaurants and hotels are located.

- the great difficulty to find parking in the urban area and in the surroundings of the Lonja and the Royal University Centre "María Cristina", due to the scarcity of this, to which is added the complicated urban structure of the town, characterized by its narrow and steep streets that hinder the circulation, both of vehicles and tourists. In addition, the excessive price of public parking and the "blue zone"19 causes the Lonja and the entrance to La Herrería to collapse, being frequent to find badly parked vehicles that cause damage to urban elements such as sidewalks, curbs and parklands ${ }^{20}$, which causes a negative perception about the Royal Site ${ }^{21}$. Although the local administration has tried to solve the situation by creating a new public car park (Terreros) and another in the heart of the city (specifically in the Plaza de la Constitución), these have only accentuated the problems of circulation in several areas of the municipality (especially in the Plaza de la Virgen de Gracia), causing a greater agglomeration of cars in the surroundings of the Lonja and the Royal University Centre due, fundamentally, to the high parking prices ${ }^{22}$.

- the lack of cleanliness and maintenance of the most touristic areas is another of the most obvious problems of the municipality, both in the urban center ${ }^{23}$ and in natural places such as Mount Abantos ${ }^{24}$. It is common to see bins in poor condition and overflowing with waste that, when they can not be deposited in the places enabled for it, end up filling the sidewalks with all kinds of waste ${ }^{25,26,27}$. With regard to the conservation of its environmental resources, it has recently been

\footnotetext{
19 The price per hour of the parking lot of Floridablanca street $\mathrm{n}$ 9 (next to the Plaza del Ayuntamiento) amounts to $€ 3$ / hour. Numerous complaints can be read at the following link:

https://www.google.com/search?q=Parking+P\%C3\%BAblico+BENCAR+EGS\%2C+S.A.\&rlz=1C1AVFC_enES 782ES782\&oq=Parking+P\%C3\%BAblico+BENCAR+EGS\%2C+S.A.\&aqs=chrome.69i57j012.394j0j9\&sourcei $\mathrm{d}=$ chrome\&ie=UTF-8\#|rd=0xd410a28816bf15d:0xa7ad8f69a5f71426,1

${ }^{20}$ See photo annex I

${ }^{21}$ https://aquienlasierra.es/san-lorenzo-de-el-escorial/el-paseo-juan-de-borbon-en-san-lorenzoescorialcerrado-al-trafico-este-fin-de-semana-por-reparaciones-urgentes-en-el-pavimento/39358/

22 See photo annex $B$

${ }^{23}$ See various points in the photo annex

${ }^{24}$ https://www.elfarodelguadarrama.com/noticia/36742/cartas-al-director/-suciedad-y-botellon-enelmonte-abantos.html

${ }^{25}$ https://www.vecinos.eu/en-japon-no-hay-papeleras/

${ }^{26}$ https://aquienlasierra.es/san-lorenzo-de-el-escorial/cartas-de-los-lectores-el-estercolero-de-laplazade-las-animas-en-san-lorenzo-de-el-escorial/40940/

${ }^{27}$ https://aquienlasierra.es/san-lorenzo-de-el-escorial/la-limpieza-viaria-aspecto-mas-cuestionadolosvecinos-san-lorenzo-la-primera-encuesta-satisfaccion-realizada-ayuntamiento/36962/
} 
proposed to limit the access of cars to La Herrería and even the so-called "Silla de Felipe II"28 by means of an Environmental Protection Plan ${ }^{29}$ that declares the aforementioned place "Protected Landscape". Likewise, it seems that the new municipal corporation intends to solve the cleaning problem that has affected the municipality for quite some time $\mathrm{e}^{30}$.

- The difficult relationship between National Heritage and the Local Administration, a fact that significantly conditions the implementation of tourism policies coordinated between both bodies. In accordance with the provisions of article 2 of Law 23/1982, of June 16, Regulating National Heritage ${ }^{31}$, the primary purpose of national heritage assets is none other than the high representation of the State, a fact that undoubtedly conditions tourist activity, which, like others, is subject to the fulfillment of its main function. However, Law 16/1985, of June 25, on Spanish Historical Heritage ${ }^{32}$ establishes that national heritage assets are subject to a visiting regime like that of other monuments of historical interest, being able to be visited freely without other limitations than those derived from maintenance or security work, as well as the fulfillment of its main objective. In the case of the Monastery of San Lorenzo de El Escorial, as well as that of other Royal Sites, there are other functions whose fulfillment must be facilitated ${ }^{33}$. The management of the Royal Site of San Lorenzo de El Escorial, like other national heritage assets, is carried out by the Board of Directors of National Heritage, an agency dependent on the Presidency of the Government. Despite the significant income generated by the visits to the Royal Sites, currently, National Heritage still does not have its own body that deals with the tourist management of its spaces, it is worth mentioning that in its Action Plan 2017-2021, a reordering and

\footnotetext{
28 https://aquienlasierra.es/monasterio-de-san-lorenzo-de-el-escorial/limitar-el-acceso-en-cocheunautobus-lanzadera-hasta-la-silla-de-felipe-ii-y-la-prohibicion-de-la-escalada-libre-entre-las-medidasquecontempla-el-plan-de-proteccion-medioambiental-de-la-herreria/45024/

${ }^{29}$ https://www.boe.es/boe/dias/2019/07/04/pdfs/BOE-A-2019-9977.pdf

30 https://aquienlasierra.es/san-lorenzo-de-el-escorial/la-alcaldesa-de-san-lorenzo-fija-comoprioridadla-puesta-en-marcha-de-un-plan-de-choque-en-materia-de-limpieza/44521/

${ }^{31}$ https://www.boe.es/buscar/act.php?id=BOE-A-1982-15230

32 https://www.boe.es/buscar/act.php?id=BOE-A-1985-12534

${ }^{33}$ Among these it is worth mentioning the celebration of various cultural events, such as educational places (Real Colegio de Alfonso XII and Real Centro Universitario "María Cristina") and scientific research (Library of the Monastery of El Escorial), as spaces of the Royal Collections (Museum of Painting and Architecture of El Escorial) and as places with religious function (celebration of Catholic worship in the Basilica of the Monastery of El Escorial and residence of the Order of Saint Agustine from 1885 ).
} 
enhancement of its resources is contemplated ${ }^{34}$. Some actions carried out by Patrimonio Nacional, without the opinion of the Local Administration, have provoked negative criticism from visitors and neighbors ${ }^{35,36,37}$, probably a consequence of this lack of coordination and understanding between both institutions that, when they join forces, generate interesting actions such as the "Train of Philip II"38,39,40.

- there is a certain exhaustion of the tourist product offered by San Lorenzo de El Escorial due, among other causes, to the competition of other places of interest within the Community of Madrid itself and neighboring provinces, as well as the scarcity of permanent alternative tourist products or of some continuity that, beyond the visit to the whole of the Monastery, motivate second visits and the arrival of new tourists ${ }^{41}$. When activities of interest have been carried out such as, for example, pictorial exhibitions in the Monastery (Hieronymus Bosch in El Escorial, 2016 ${ }^{42}$ ), musical cycles in the Auditorium Theater and the recent dramatized visits to the Royal Coliseum of Charles III $^{43}$ have attracted visitors and, in a way, have meant an attempt to diversify the tourist offer that should have continuity and greater promotion by the administrations ${ }^{44,45,46}$.

\footnotetext{
34 https://www.patrimonionacional.es/sites/default/files/2019-02/plan_de_actuacion_20172021_web.pdf

${ }^{35}$ https://www.elmundo.es/madrid/2015/08/02/55be51b946163f544c8b4572.html

${ }^{36}$ https://www.capitalnoroeste.es/cultura/los-vecinos-de-san-lorenzo-de-el-escorial-unidos-encontradel-cierre-de-las-salas-del-monasterio/

${ }^{37}$ https://www.change.org/p/patrimonio-nacional-no-m\%C3\%A1s-cierres-en-el-monasterio-deelescorial

38 https://www.trendefelipeii.com/es/

${ }^{39}$ https://madridpress.com/art/228685/san-lorenzo-de-el-escorial-y-patrimonio-nacional-Ianzanuntren-turistico

${ }^{40}$ https://www.boe.es/diario_boe/txt.php?id=BOE-A-2017-10629

${ }^{41}$ https://entornoescorial.blogspot.com/2016/02/dos-metas-para-san-lorenzo-conservar.html

42 https://www.patrimonionacional.es/colecciones-reales/exposicionestemporales/exposicionesanteriores/el-bosco-en-el-escorial-v-centenario

${ }^{43}$ https://aquienlasierra.es/san-lorenzo-de-el-escorial/el-real-coliseo-carlos-iii-de-san-lorenzo-poneenmarcha-un-programa-de-visitas-teatralizadas/40362/

${ }^{44}$ https://scherzo.es/el-escorial-el-vuelo-declinante-de-la-mariposa/

45 https://elpais.com/ccaa/2013/05/26/madrid/1369582043_071108.html

${ }^{46}$ https://aquienlasierra.es/san-lorenzo-de-el-escorial/teresa-berganza-una-pena-habersegastadotanto-dinero-auditorio-san-lorenzo-este-asi/36008/
} 
In addition, various tourism initiatives presented at FITUR have been launched, such as the virtual applications "San Lorenzo 360" "47,48, and "Marco Topo"49,50.

- the excessive municipal taxes levied on catering and hospitality services, which in turn have an impact on the rise in the prices of goods offered to visitors. There are many complaints and unease among local businessmen for several years on this issue ${ }^{51}$ that, together with a period of economic crisis that began in 2008 , has caused the closure of numerous businesses ${ }^{52}$. Aware of this, the new municipal government recently announced the upcoming approval, among other measures, of a "zero quota" for new entrepreneurs ${ }^{53}$.

These are some of the challenges to which the different institutions (National Heritage) and public administrations of local and regional scope must provide solutions that guarantee the sustainability of San Lorenzo de El Escorial as an outstanding tourist destination that, although it is still one of the most visited places in the Community of Madrid, in 2018 recorded a decrease of 16,000 visitors compared to previous years ${ }^{54}$.

\section{PROJECTED PLANNING}

For the elaboration of the development of sustainable tourism in San Lorenzo de El Escorial, it is contemplated the realization of several actions that can be subject to subsequent modification according to the circumstances. As far as the planning phases are concerned, they will initially be:

- identification and analysis of the current situation of tourist activity in San Lorenzo de El Escorial, as well as the agents involved.

- search for bibliographic information both in libraries and through the Internet. Information will also be obtained from different public bodies such as the City

\footnotetext{
47 https://aquienlasierra.es/san-lorenzo-de-el-escorial/san-lorenzo-360o-nominada-al-premiocomomejor-aplicacion-turistica-en-el-marco-de-fitur/38074/

${ }^{48}$ https://6dlab.com/san-lorenzo-de-el-escorial-vr/

${ }^{49}$ https://aquienlasierra.es/san-lorenzo-de-el-escorial/san-lorenzo-de-el-escorial-presenta-suofertaturistica-en-fitur-con-novedades-como-la-aplicacion-marco-topo/38396/

$50 \mathrm{https}: / /$ marcotopo.com/aventura/madrid-san-lorenzo-de-el-escorial-turismo-en-familia/

51 https://www.vecinos.eu/conoces-a-tu-vecino-jose-wanguemert/

52 https://www.elfarodelguadarrama.com/noticia/51717/san-lorenzo/veinte-anos-despues-elparqueempresarial-de-san-lorenzo-sigue-en-obras-y-sin-fecha-de-apertura.html

${ }^{53}$ https://aquienlasierra.es/san-lorenzo-de-el-escorial/cuota-cero-emprenedores/49482/

${ }^{54}$ https://aquienlasierra.es/monasterio-de-san-lorenzo-de-el-escorial/el-monasterio-de-san-lorenzodeel-escorial-pierde-16-000-visitantes-en-2018-aunque-se-mantiene-como-el-segundo-monumentomasvisitado-de-patrimonio-nacional/37605/
} 
Council of San Lorenzo de El Escorial, Tourism of the Community of Madrid and National Heritage.

- field research in the municipality of San Lorenzo de El Escorial to obtain firsthand, data and observations that allow to answer the questions raised regarding the current state of tourism activity. It contemplates the possibility of conducting surveys in a personal or virtual way, both to visitors and to neighbors, to know their opinions.

- once the necessary information has been obtained, a plan will be drawn up containing various measures whose implementation will help to solve the challenges faced by San Lorenzo de El Escorial as a tourist destination, and which will enable its future sustainability.

\section{CONCLUSION}

In order for San Lorenzo de El Escorial to maintain its position as one of the most attractive tourist destinations in the Community of Madrid, an exhaustive analysis of its current situation and in which areas it needs to improve should be carried out, in order to subsequently implement the necessary measures to correct these deficiencies, rethink the viability of its current tourism model and its future sustainability. The measures to be adopted by the agents involved, whether public or private entities or through the cooperation of both, should be aimed at solving, in the short and medium term, several basic problems:

- to ensure that visitors prolong their presence in the municipality and with it, overnight stays.

- diversify the tourist offer and present it in new market niches.

- promote other tourist attractions of the municipality to relieve the tourist pressure that is concentrated in a very specific area, and provoke second and successive visits through activities that attract the attention of visitors.

- establish a program of maintenance and general cleaning of the town, a fact that generates criticism from both residents and visitors.

Although the local administration had a Tourism Excellence Plan between 2003 and $2006^{55}$, the crisis that began in 2008 , as well as various local political incidents, have

\footnotetext{
55 https://www.hosteltur.com/comunidad/nota/009916_el-plan-de-excelencia-turistica-de-sanlorenzode-el-escorial-cuenta-con-una-dotacion-de-162-millones-de-euros.html
} 
prevented the objectives set from having not yet been carried out. It is hoped that the new municipal government will become aware of the great importance of tourism for the development of the town and of the measures that should be applied for its future sustainability, perhaps through the elaboration of a new Tourism Excellence Plan that will address both present and future challenges.

\section{BIBLIOGRAPHY}

- Altimira Vega, R.; Muñoz Vivas, X.; (2007) El turismo como motor de crecimiento económico; Anuario Jurídico y Económico Escurialense, XL, 677-710

- Bustamante Humanes, A. (2009) Guía del Real Sitio de El Escorial: monasterio y territorio; Comunidad de Madrid

- Calle Vaquero, M.; García Hernández, M. (1998) Ciudades históricas: patrimonio cultural y recurso turístico; Ería, $n^{\circ} 47,249-266$

- Celdrán Bernabeu, M.A. (2014) "Estrategias y políticas de turismo sostenible” en Canyelles i Pastó, J.M.; Celdrán Bernabeu, M.A.; Grünig Iribarren, S. \& March Corbella, H.; Sostenibilidad y turismo, Barcelona: Oberta UOC Publishing

- García Hernández, M.; Mínguez García, Ma C. (2005) Funcionalidad turística de los Reales Sitios Españoles: problemas y perspectivas; Ería, $n^{\circ} 66,71-84$

• Grünig Iribarren, S. (2014) "Marco conceptual: los tres ejes de la sostenibilidad" en Canyelles i Pastó, J.M.; Celdrán Bernabeu, M.A.; Grünig Iribarren, S. \& March Corbella, H.; Sostenibilidad y turismo, Barcelona: Oberta UOC Publishing - Lynch, J. (2000) Los Austrias: 1516-1700, Barcelona: Editorial Crítica

- Mínguez García, Mª C. (2007) Planificación y Gestión Turística en destinos patrimoniales: el caso del Real Sitio de San Lorenzo de El Escorial (Comunidad de Madrid); Anales de Geografía, vol. 27, no 1, 83-102

- Ortega Martínez, E.; Such Devesa, M.J. (2013) Comunicación y conocimiento del patrimonio mundial de la Comunidad de Madrid; Cuadernos de Turismo, $n^{o} 31,263$ 288

- Troitiño Vinuesa, M.A.; Calle Vaquero, M.; García Hernández, M.; Troitiño Torralba, L. (2005) La funcionalidad turística del patrimonio cultural (B.I.C.) de la Comunidad de Madrid y estrategias de actuación; Dirección General de Turismo (Consejería de Economía e Innovación Tecnológica Comunidad de Madrid) 
- Velasco González, M. (2009) Gestión turística del Patrimonio Cultural: enfoques para un desarrollo sostenible del turismo cultural; Cuadernos de Turismo, $n^{\circ}$ 23, 237-253

\section{ANNEXES}

\section{INTERNET RESOURCES}

- DECRETO 52/2006, de 15 de junio, por el que se declara bien de interés cultural, en la categoría de territorio histórico, el Real Sitio de San Lorenzo de El Escorial constituido por el ámbito delimitado por la Cerca Histórica de Felipe II. - Boletín Oficial de la Comunidad de Madrid, de 21-06-2006: https://www.iberley.es/legislacion/decreto-52- 2006-15-junio-declara bien-interescultural-categoria-territorio-historico-real-sitio-sanlorenzo-escorial-constituido-ambitodelimitado-historica-felipe-ii-3781795 (accessed October 2019)

- Ley 7/2013, de 25 de junio, de declaración del Parque Nacional de la Sierra de Guadarrama: https://www.boe.es/buscar/doc.php?id=BOE-A-2013-6900 (accessed October 2019)

- Anuario Estadístico de España 2017:

https://www.ine.es/prodyser/pubweb/anuario17/anu17_01entor.pdf (accessed October 2019)

- Ley de Patrimonio de 1932, de 22 de marzo: https://www.boe.es/datos/pdfs/BOE/1932/084/A02067-02069.pdf (accessed October 2019)

- Decreto 1857/1971, de 8 de julio, por el que se declara conjunto histórico-artístico determinadas zonas del Real Sitio de San Lorenzo de El Escorial: https://www.boe.es/diario_boe/txt.php?id=BOE-A-1971-43675 (accessed October 2019)

- Búsqueda de bienes declarados Patrimonio Mundial en España: https://web.archive.org/web/20091107191045/http://www.mcu.es/patrimonio/MC/PME /B ienesDec/ListadoBienes/Escorial.html (accessed October 2019)

- Decreto 2418/1961, de 16 de noviembre, por el que se declara Pintoresco el Pinar de Abantos y Zona de la Herrería del Real Sitio de San Lorenzo del Escorial (Madrid): https://www.boe.es/diario_boe/txt.php?id=BOE-A-1961-22493 (accessed October 
2019)

- LIC ES 3110005 "Cuenca del rio Guadarrama":

http://www.madrid.org/es/transparencia/informacion-

institucional/planesprogramas/plan-gestion zona-especial-conservacion-es3110005cuenca (accessed October 2019)

- Nomenclátor: Población del Padrón Continuo por Unidad Poblacional:

https://www.ine.es/nomen2/index.do (accessed October 2019)

- Navarro, A. (4 de marzo de 2019) Cartas de los lectores. - "El ocaso de la calle Pozas", Aquí en la Sierra: https://aquienlasierra.es/san-lorenzo-de-elescorial/cartas-delos lectores-el-ocaso-de-la-calle-pozas/39993/ (accessed October 2019)

- Vecinos San Lorenzo de El Escorial (7 de marzo de 2019) ¿Revitalizamos el comercio de San Lorenzo? Recuperado de: https://www.vecinos.eu/revitalizamos-el-comerciodesan-lorenzo/ (accessed October 2019)

- El Palacio Real de Madrid, el más visitado de España en 2018 (3 de enero de 2019), Madrid es noticia : https://www.madridesnoticia.es/2019/01/palacio-realmadrid-masvisitado-espana-2018/ (accessed October 2019)

- Riaño, P.H. (3 de enero de 2019) Las visitas al Valle de los Caídos subieron un 33,5\% el año pasado respecto a 2017, El País :

https://elpais.com/cultura/2019/01/03/actualidad/1546533314_068761.html (accessed October 2019)

- Real Coliseo Carlos III de San Lorenzo de El Escorial:

http://www.comunidad.madrid/centros/real-coliseo-carlos-iii-san-lorenzo-escorial (accessed October 2019)

- Teatro Auditorio de San Lorenzo de El Escorial:

http://www.comunidad.madrid/centros/teatro-auditorio-san-lorenzo-escorial (accessed October 2019)

- Belén de San Lorenzo de El Escorial: https://todosobremadrid.com/que-hacer/belendesan lorenzo-de-el-escorial/ (accessed October 2019) Instituto de Estadística: http://www.madrid.org/desvan/desvan/AccionDatosUnaSerie.icm?codTema=1302068\& codMun=1317 (accessed October 2019)

- Universidad Complutense de Madrid - Programación Cursos de Verano: https://www.ucm.es/cursosdeverano/programacion (accessed October 2019) - Euroforum: https://www.euroforum.es/ (consulta octubre 2019) 
- Ruta por el siglo XVI: https://sanlorenzoturismo.es/es/ruta-por-el-siglo-Xvi (accessed October 2019)

- Ruta por el siglo XVIII: https://sanlorenzoturismo.es/es/ruta-por-el-siglo-Xviii (accessed October 2019)

- Parking Público BENCAR EGS, S.A:

https://www.google.com/search?q=Parking+P\%C3\%BAblico+BENCAR+EGS\%2C+S. A.\&rlz=1C1AVFC_enES782ES782\&oq=Parking+P\%C3\%BAblico+BENCAR+EGS\% $2 \mathrm{C}+$ S.A. $\&$ aqs $=$ chrome $.69 \mathrm{i} 57 \mathrm{j} 012.394 \mathrm{j} 0 \mathrm{j} 9 \&$ sourceid $=$ chrome $\& \mathrm{ie}=\mathrm{UTF}-$ 8\#lrd=0xd410a28816bf15d:0xa7ad8f69a5f71426,1, (accessed October 2019)

- Redacción (15 de febrero de 2019) El Paseo Juan de Borbón, en San Lorenzo de El Escorial, cerrado al tráfico este fin de semana por "reparaciones urgentes en el pavimento", Aquí en la Sierra : https://aquienlasierra.es/san-lorenzo-deel-escorial/elpaseo-juan-de-borbon-en-san-lorenzo-escorial-cerrado-al-trafico-este-finde-semana-porreparaciones-urgentes-en-el-pavimento/39358/ (accessed October 2019)

- Ruíz, J.A. (22 de octubre de 2014) Suciedad y botellón en el monte Abantos, El Faro del Guadarrama: https://www.elfarodelguadarrama.com/noticia/36742/cartas-aldirector/-suciedad-ybotellon-en-el-monte-abantos.html (accessed October 2019) - Vecinos de San Lorenzo de El Escorial (31 de octubre de 2018) En Japón no hay papeleras : https://www.vecinos.eu/en-japon-no-hay-papeleras/ (accessed October 2019) - Pérez, J. (22 de marzo de 2019) Cartas de los lectores. - "El estercolero de la plaza de las Ánimas en San Lorenzo de El Escorial”, Aquí en la Sierra: https://aquienlasierra.es/san-lorenzo-de-el-escorial/cartas-de-los-lectores-elestercolerode-la-plaza-de-las-animas-en-san-lorenzo-de-el-escorial/40940/ (accessed October 2019)

- Redacción (5 de diciembre de 2018) La limpieza viaria, el aspecto más cuestionado por los vecinos de San Lorenzo en la primera encuesta de satisfacción realizada por el Ayuntamiento, Aquí en la Sierra : https://aquienlasierra.es/san-lorenzode-el-escorial/lalimpieza-viaria-aspecto-mas-cuestionado-los-vecinos-san-lorenzo-laprimera-encuestasatisfaccion-realizada-ayuntamiento/36962/ (accessed October 2019)

- Redacción (13 de julio de 2019) Limitar el acceso en coche, un autobús-lanzadera hasta la Silla de Felipe II y la prohibición de la escalada, entre las medidas que contempla el Plan de Protección de La Herrería, Aquí en la Sierra: https://aquienlasierra.es/monasterio-de-san-lorenzo-de-el-escorial/limitar-el-acceso- 
encoche-un-autobus-lanzadera-hasta-la-silla-de-felipe-ii-y-la-prohibicion-de-laescaladalibre-entre-las-medidas-que-contempla-el-plan-de-proteccion-medioambientalde-laherreria/45024/ (accessed October 2019)

- BOE 4 de julio de 2019, PLAN DE PROTECCIÓN MEDIOAMBIENTAL DEL BOSQUE DE LA HERRERÍA: https://www.boe.es/boe/dias/2019/07/04/pdfs/BOE-A2019-9977.pdf (accessed October 2019)

- Ley 16/1985, de 25 de junio, del Patrimonio Histórico Español: https://www.boe.es/buscar/act.php?id=BOE-A-1985-12534 (accessed October 2019)

- Plan de Actuación de Patrimonio Nacional 2017-2021: https://www.patrimonionacional.es/sites/default/files/2019-02/plan_de_actuacion_20172021_web.pdf (accessed October 2019)

- Ollero, D.J. (3 de agosto de 2015) Polémico cierre en el Monasterio de El Escorial, El Mundo: https://www.elmundo.es/madrid/2015/08/02/55be51b946163f544c8b4572.html (accessed October 2019)

- Bueno, C. (15 de septiembre de 2015) Los vecinos de San Lorenzo de El Escorial, unidos en contra del cierre de las salas del Monasterio, Capital Noroeste: https://www.capitalnoroeste.es/cultura/los-vecinos-de-san-lorenzo-de-el escorialunidosen-contra-del-cierre-de-las-salas-del-monasterio/ (accessed October 2019)

- Patrimonio Nacional: no más cierres en el Monasterio de El Escorial: https://www.change.org/p/patrimonio-nacional-no-m\%C3\%A1s-cierres-enelmonasterio-de-el-escorial (accessed October 2019)

- Tren de Felipe II: https://www.trendefelipeii.com/es/ (accessed October 2019)

- Redacción (9 de octubre de 2017) San Lorenzo de El Escorial y Patrimonio Nacional lanzan un tren turístico, Madridpress.com : https://madridpress.com/art/228685/sanlorenzo-de-el-escorial-y-patrimonio-nacionallanzan-un-tren-turistico (accessed October 2019)

- Resolución de 4 de septiembre de 2017, de la Gerencia del Consejo de Administración del Patrimonio Nacional, por la que se publica el Convenio de colaboración con los Ayuntamientos de El Escorial y San Lorenzo de El Escorial, para la puesta en funcionamiento de un tren turístico ("Diligencia de El Escorial") en el Real Sitio de San Lorenzo de El Escorial: https://www.boe.es/diario_boe/txt.php?id=BOE-A-2017-10629 (accessed October 2019) 
- Dos metas para San Lorenzo: conservar patrimonio y atraer turismo de calidad, Entorno Escorial: https://entornoescorial.blogspot.com/2016/02/dos-metas-para-sanlorenzoconservar.html (consulta octubre 2019)

- El Bosco en El Escorial. V Centenario:

https://www.patrimonionacional.es/coleccionesreales/exposicionestemporales/exposicio nes-anteriores/el-bosco-en-el-escorial-vcentenario (accessed October 2019)

- Redacción (11 de marzo de 2019) El Real Coliseo Carlos III de San Lorenzo pone en marcha un programa de visitas teatralizadas, Aquí en la Sierra :https://aquienlasierra.es/san-lorenzo-de-el-escorial/el-real-coliseo-carlos-iii-desanlorenzo-pone-en-marcha-un-programa-de-visitas-teatralizadas/40362/ (accessed October 2019)

- Reverter, A. (27 de julio de 2019) El vuelo declinante de la mariposa, Scherzo. Recuperado de: https://scherzo.es/el-escorial-el-vuelo-declinante-de-la-mariposa/ (accessed October 2019)

- Sánchez, E. (27 de mayo de 2013) Un auditorio de 99,5 millones infrautilizado, El País : https://elpais.com/ccaa/2013/05/26/madrid/1369582043_071108.html (accessed October 2019)

- Peñas, E. y Rubio, T. (7 de noviembre de 2018) Teresa Berganza: "Es una pena haberse gastado tanto dinero en el Auditorio de San Lorenzo para que esté así", Aquí en la Sierra : https://aquienlasierra.es/san-lorenzo-de-el-escorial/teresa-berganzauna-penahaberse-gastado-tanto-dinero-auditorio-san-lorenzo-este-asi/36008/ (accessed October 2019)

- Redacción (16 de enero de 2019) San Lorenzo 360 ${ }^{\circ}$, nominada al premio como mejor aplicación turística en el marco de FITUR, Aquí en la Sierra :

https://aquienlasierra.es/san-lorenzo-de-el-escorial/san-lorenzo-360o-nominadaalpremio-como-mejor-aplicacion-turistica-en-el-marco-de-fitur/38074/ (accessed October 2019)

-SAN LORENZO DE EL ESCORIAL VR [APP]: https://6dlab.com/san-lorenzo-deelescorial-vr/ (accessed October 2019)

- Redacción (24 de enero de 2019) San Lorenzo de El Escorial presenta su oferta turística en FITUR, con novedades como la aplicación "Marco Topo", Aquí en la Sierra.: https://aquienlasierra.es/san-lorenzo-de-el-escorial/san-lorenzo-de-elescorialpresenta-su-oferta-turistica-en-fitur-con-novedades-como-la-aplicacion- 
marcotopo/38396/ (accessed October 2019)

- Vecinos San Lorenzo de El Escorial (4 de abril de 2014) ¿Conoces a tu vecino... José Wangüemert?: https://www.vecinos.eu/conoces-a-tu-vecino-jose-wanguemert/ (accessed October 2019)

- Redacción (12 de agosto de 2019) Veinte años después, el Parque Empresarial de San Lorenzo sigue en obras y sin fecha de apertura, El Faro del Guadarrama : https://www.elfarodelguadarrama.com/noticia/51717/san-lorenzo/veinte-anosdespuesel-parque-empresarial-de-san-lorenzo-sigue-en-obras-y-sin-fecha-deapertura.html (accessed October 2019)

- Redacción (16 de octubre de 2019) El Ejecutivo de San Lorenzo aprueba una 'cuota cero' para emprendedores, Aquí en la Sierra. Recuperado de: https://aquienlasierra.es/san-lorenzo-de-el-escorial/cuota-cero-emprenedores/49482/ (accessed October 2019)

- Redacción (3 de enero de 2019) El Monasterio de San Lorenzo de El Escorial pierde 16.000 visitantes en 2018, aunque se mantiene como el segundo monumento más visitado de Patrimonio Nacional, Aquí en la Sierra : https://aquienlasierra.es/monasterio-de-san-lorenzo-de-el-escorial/el-monasterio-desanlorenzo-de-el-escorial-pierde-16-000-visitantes-en-2018-aunque-se-mantienecomo-elsegundo-monumento-mas-visitado-de-patrimonio-nacional/37605/ (accessed October 2019)

- Redacción (16 de noviembre de 2004) El Plan de Excelencia Turística de San Lorenzo de El Escorial cuenta con una dotación de 1,62 millones de euros, Hosteltur : https://www.hosteltur.com/comunidad/nota/009916_el-plan-de-excelencia-turisticadesan-lorenzo-de-el-escorial-cuenta-con-una-dotacion-de-162-millones-de-euros.html (accessed October 2019) 


\section{MAPS AND PICTURES}

\section{Tourist area of San Lorenzo de El Escorial (Source: Google Maps)}

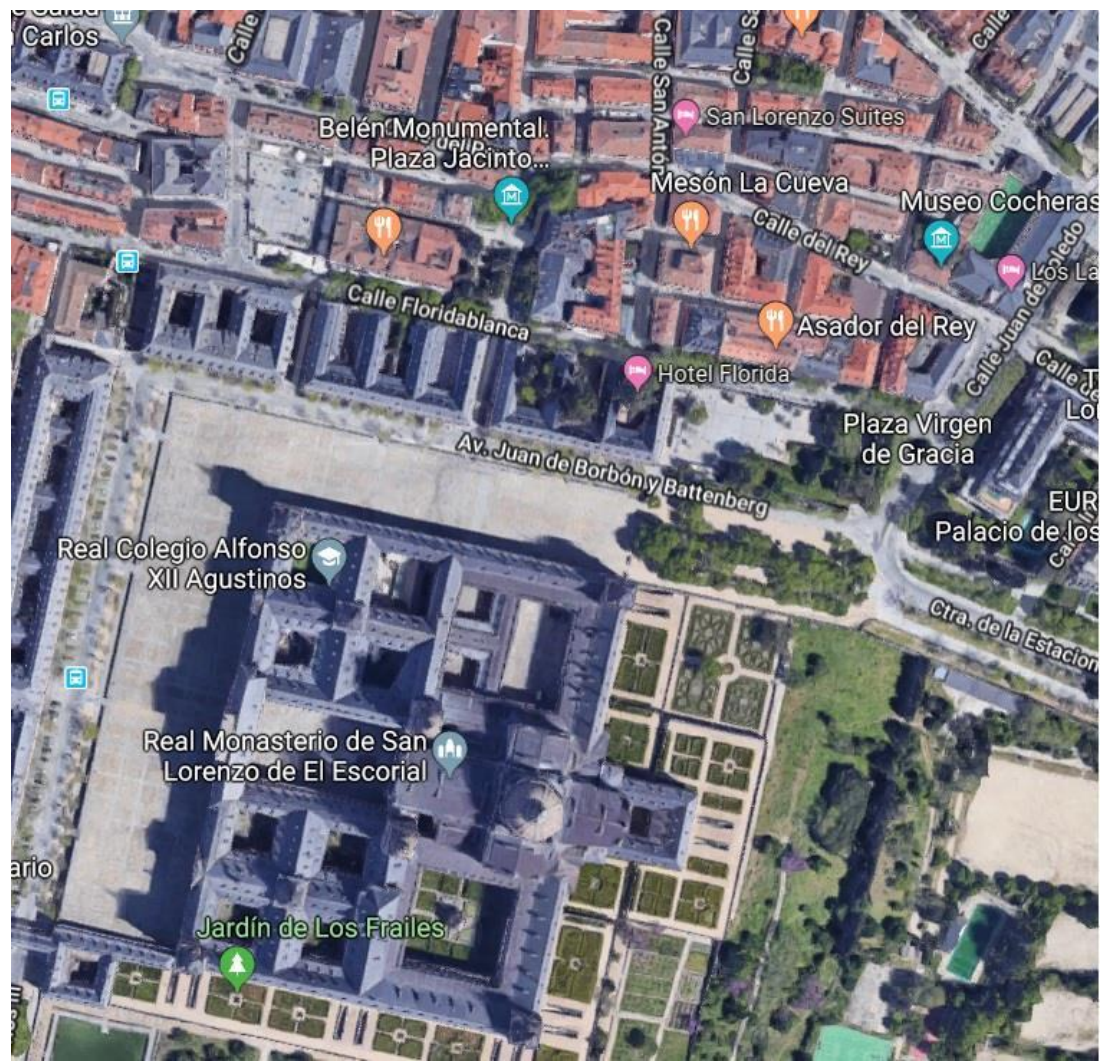

2. Hotel beds in San Lorenzo de El Escorial (2008-2018) Source: INE

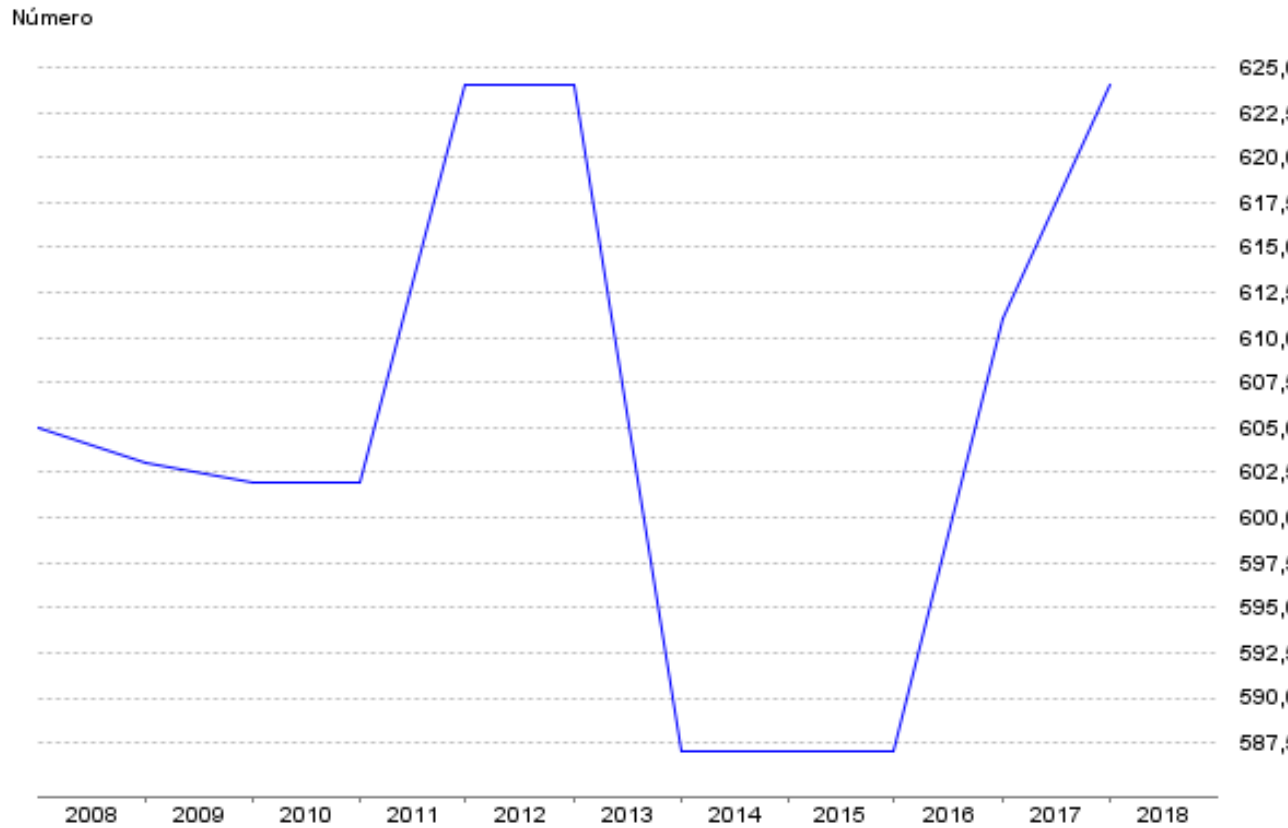


(C) Mario Martín Merino, 2021

\section{PHOTOGRAPHIC ANNEX}

Selection of more than 100 photographs taken in the most touristic area of San Lorenzo de El Escorial between October 28 and November 2, 2019 by the author.

\section{A. Las Pozas Street}
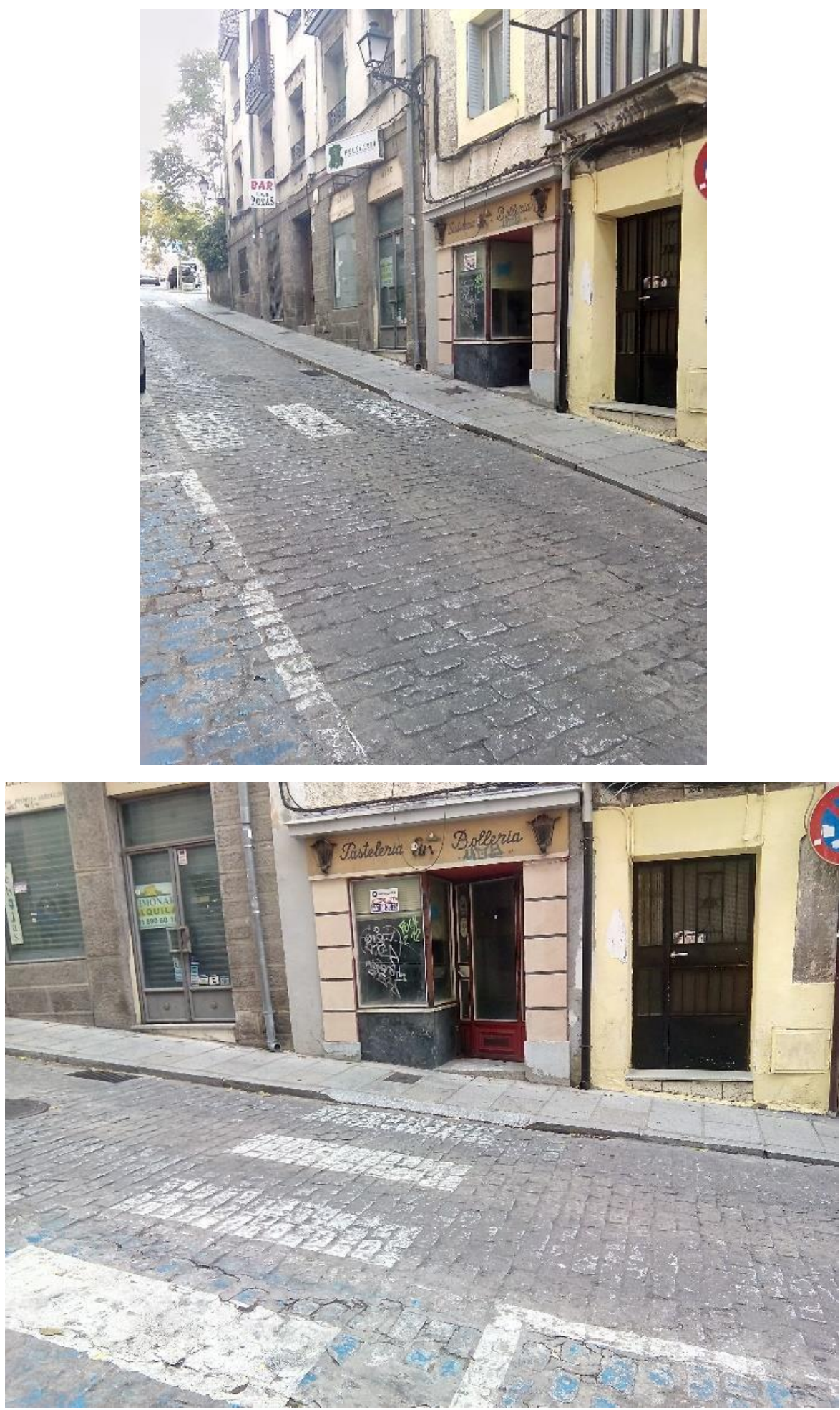
(C) Mario Martín Merino, 2021
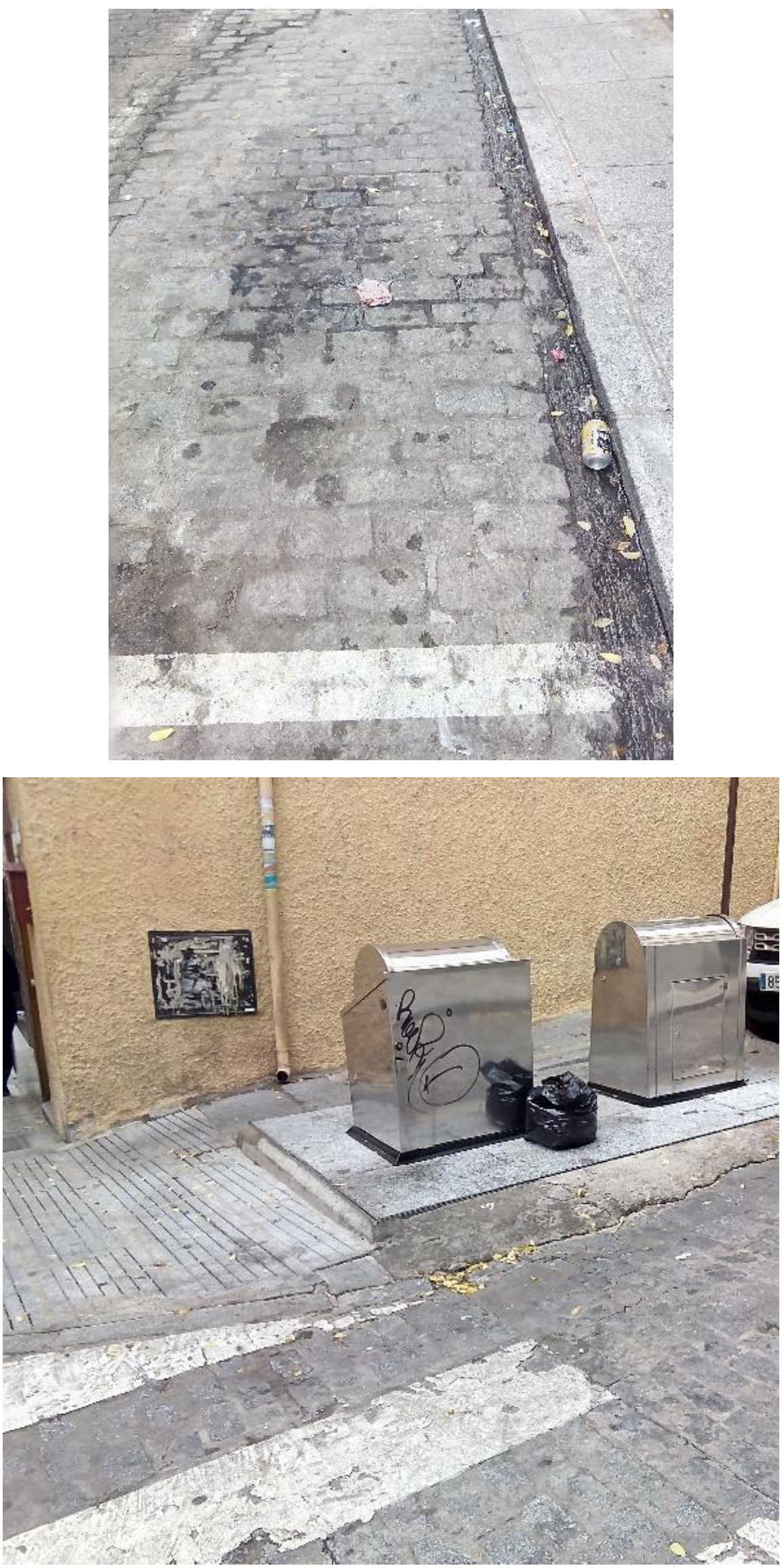


\section{B. Parking meters in the tourist area and current parking rates}
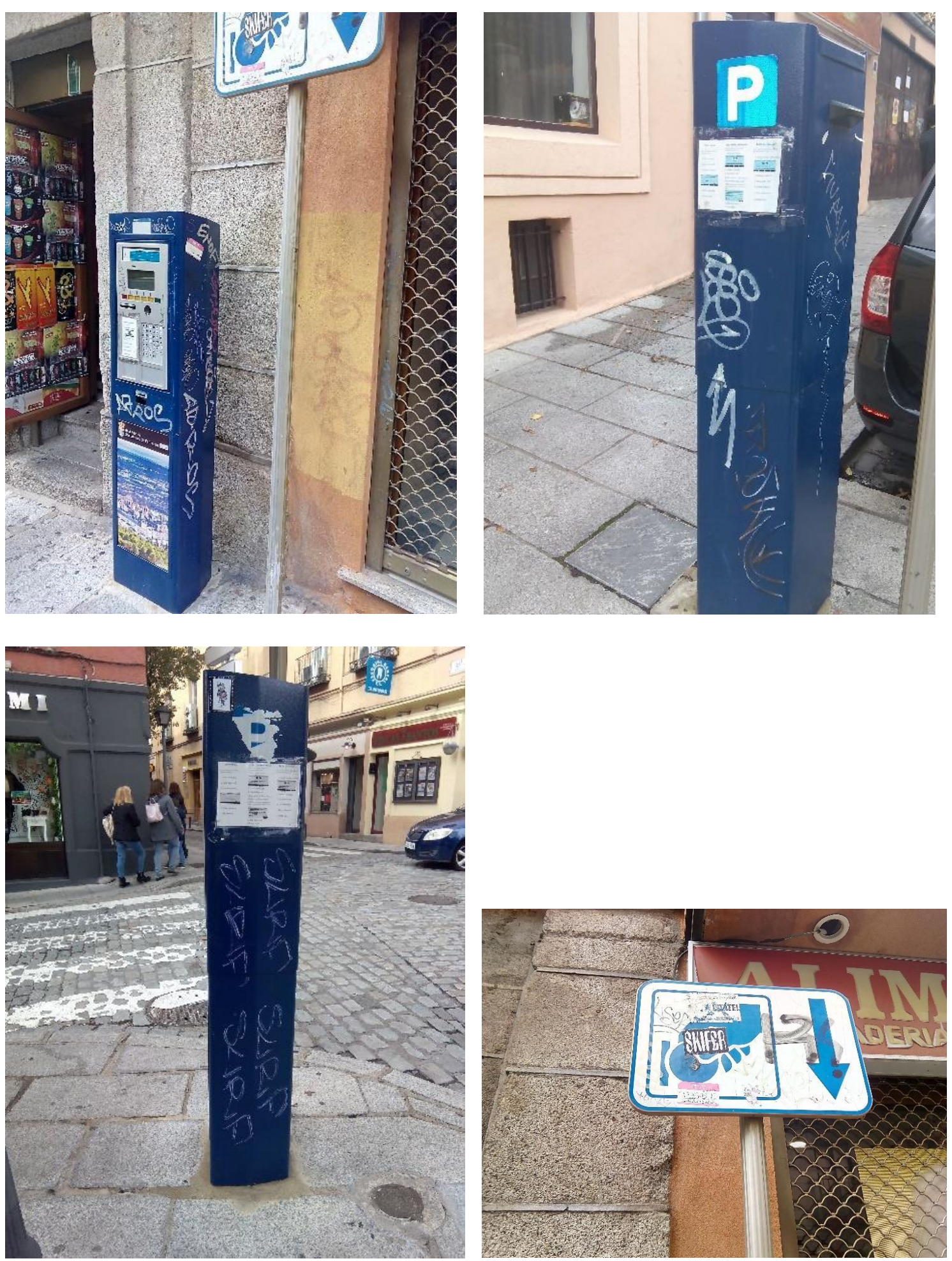
(C) Mario Martín Merino, 2021

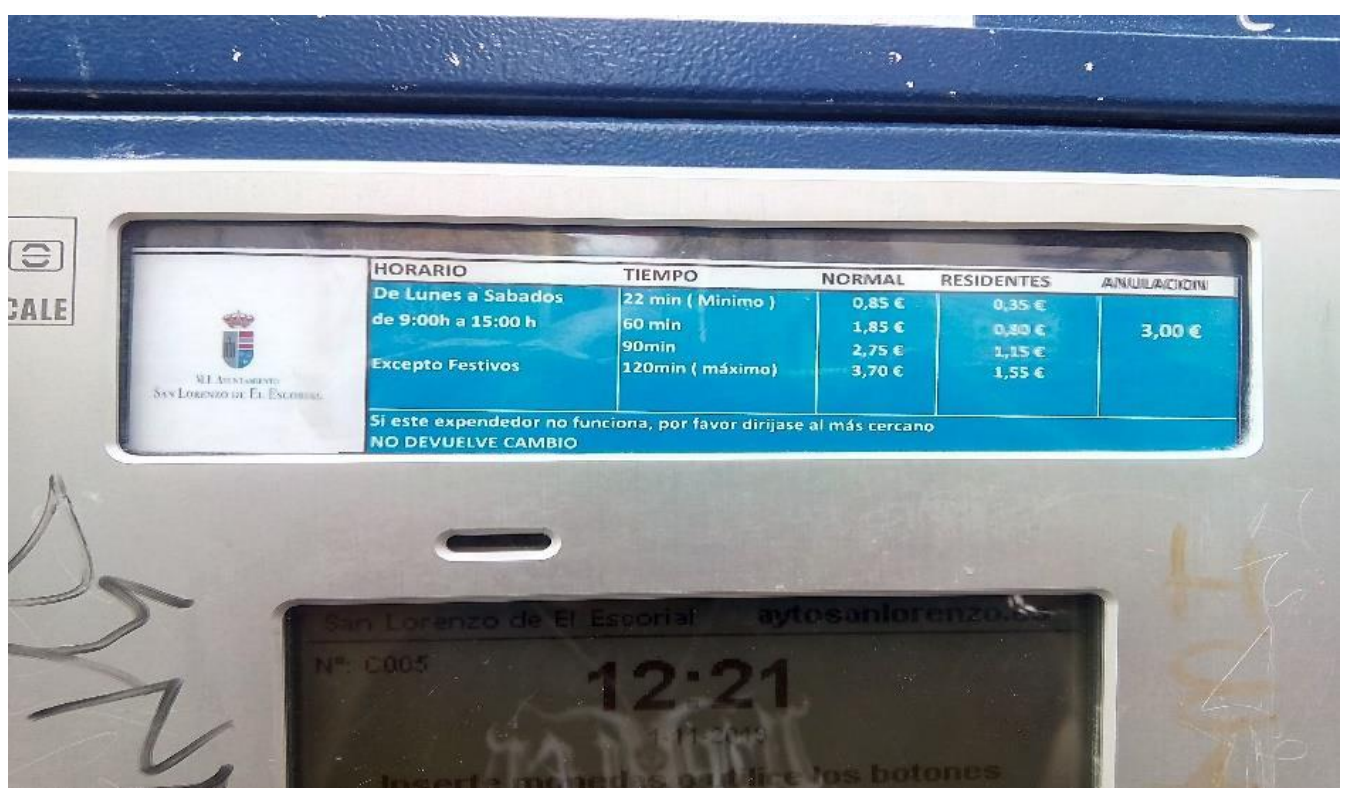

\section{Tourist information items}
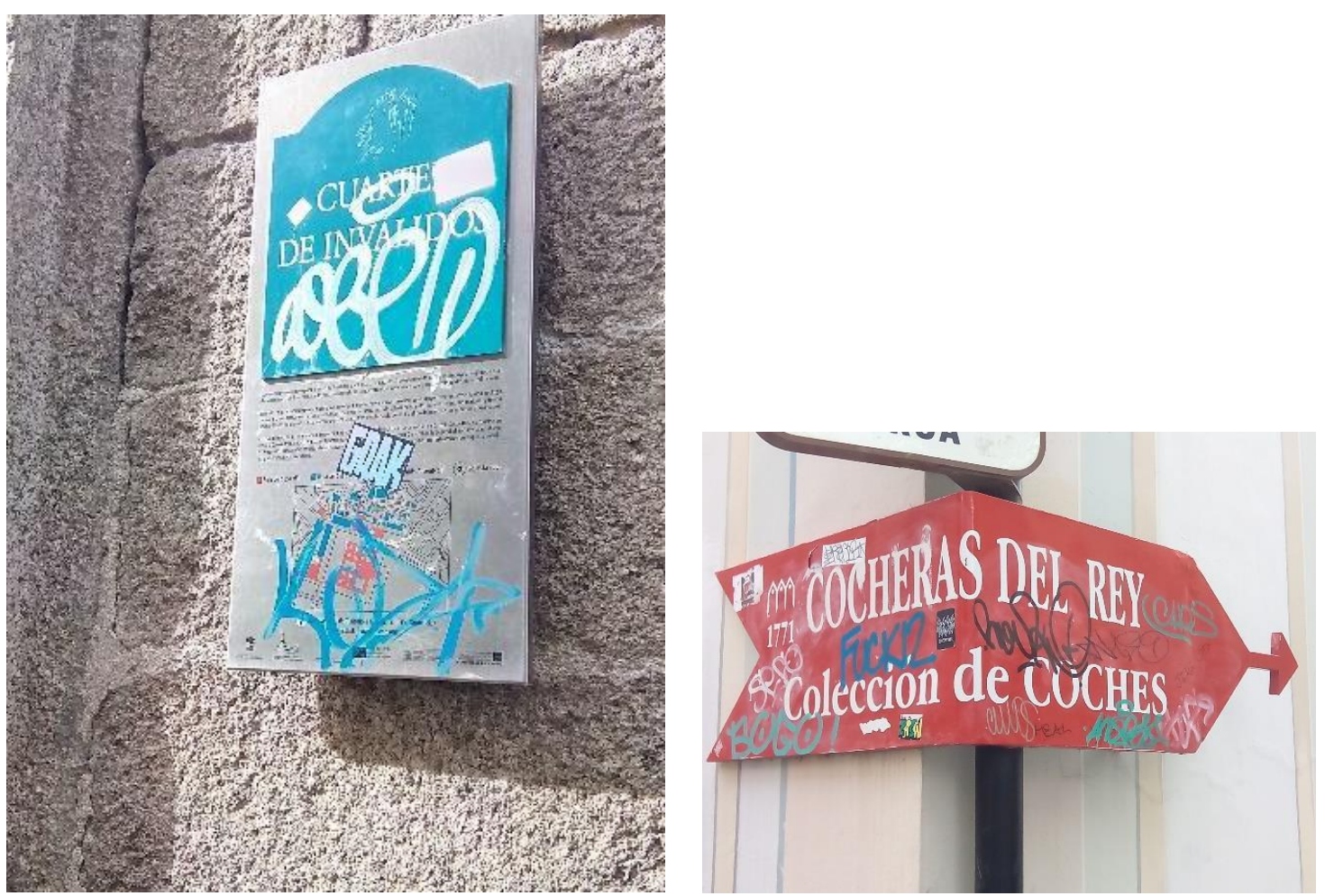
(C) Mario Martín Merino, 2021
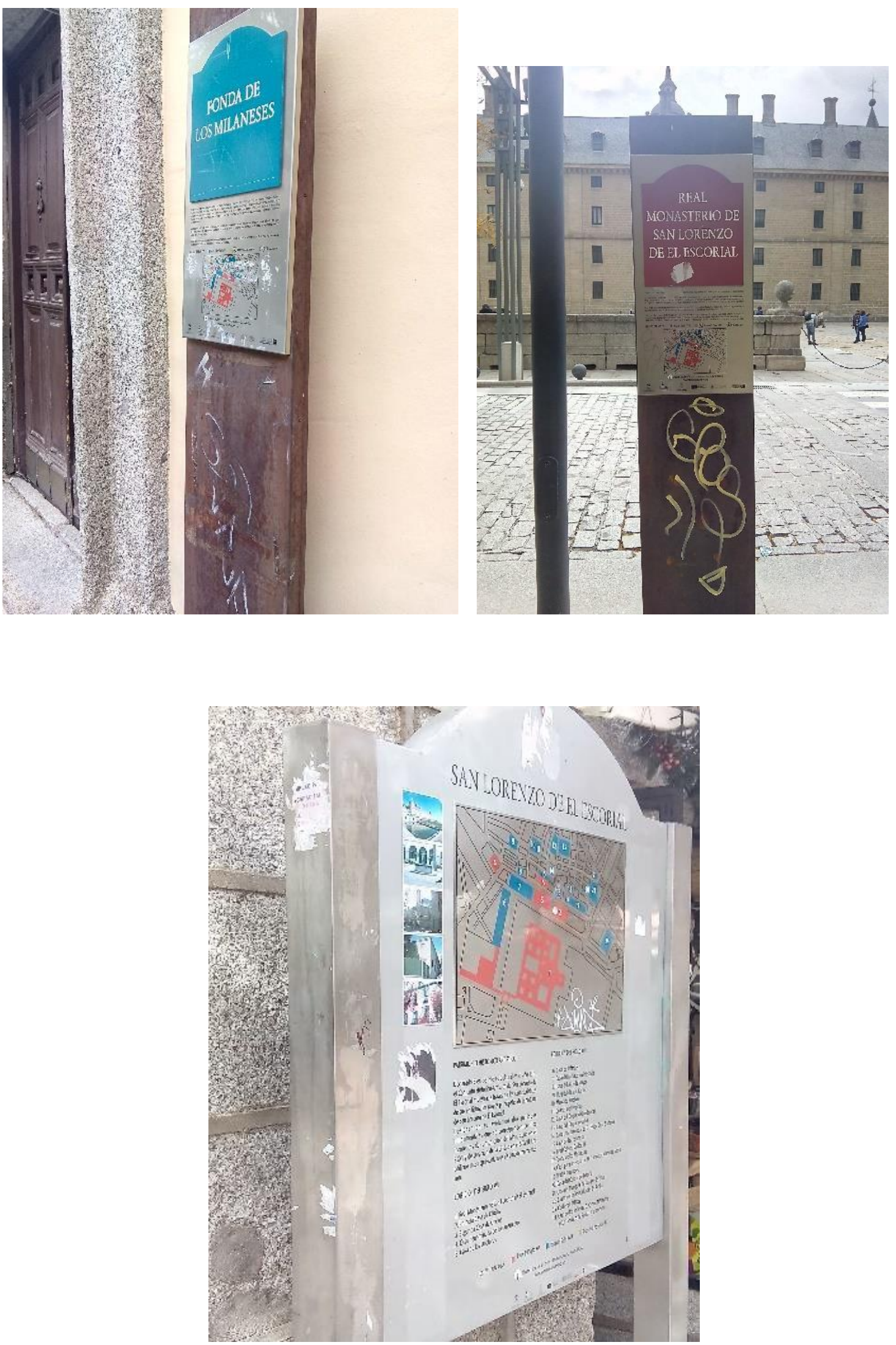
(C) Mario Martín Merino, 2021
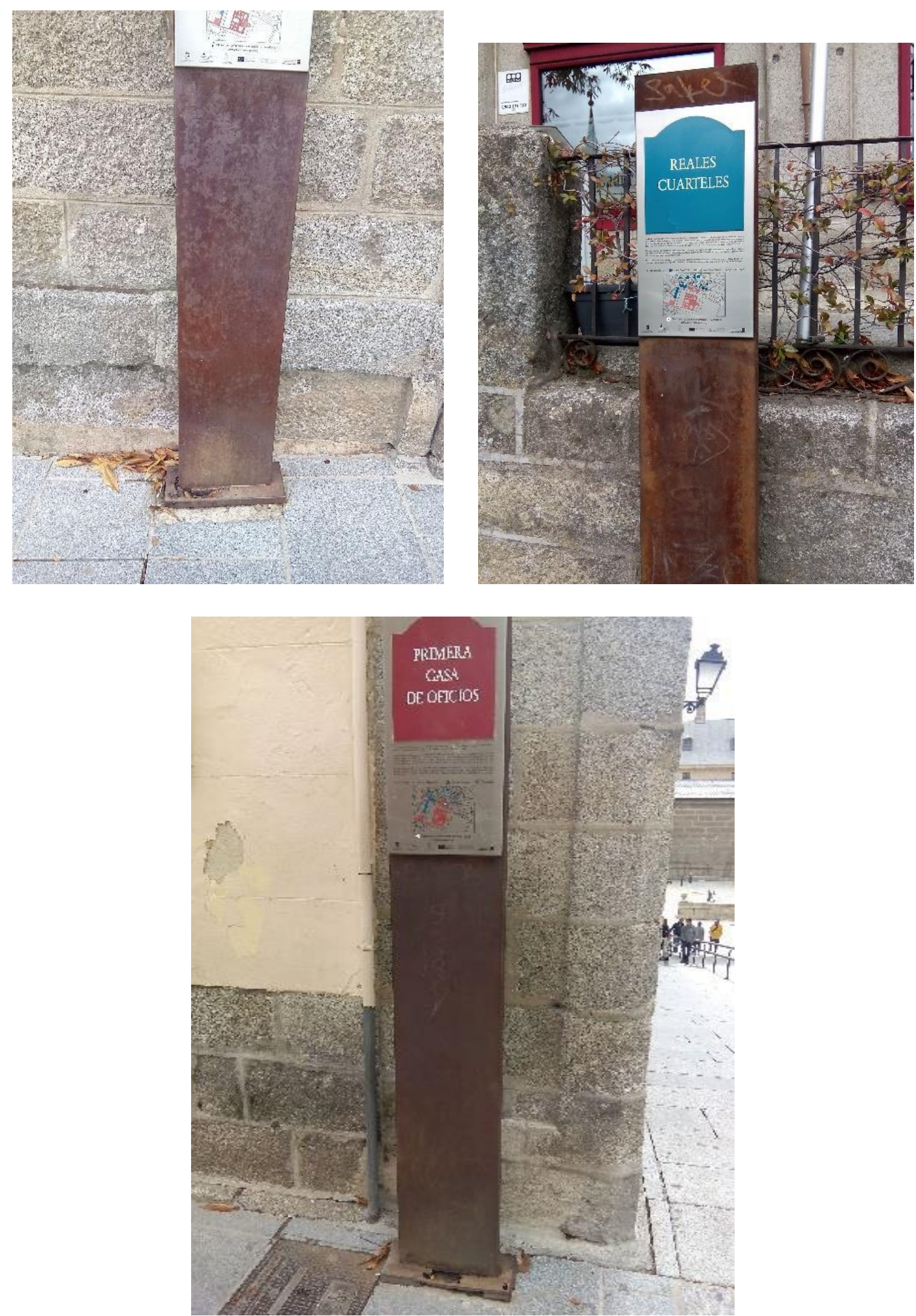
(C) Mario Martín Merino, 2021

\section{Other ítems}
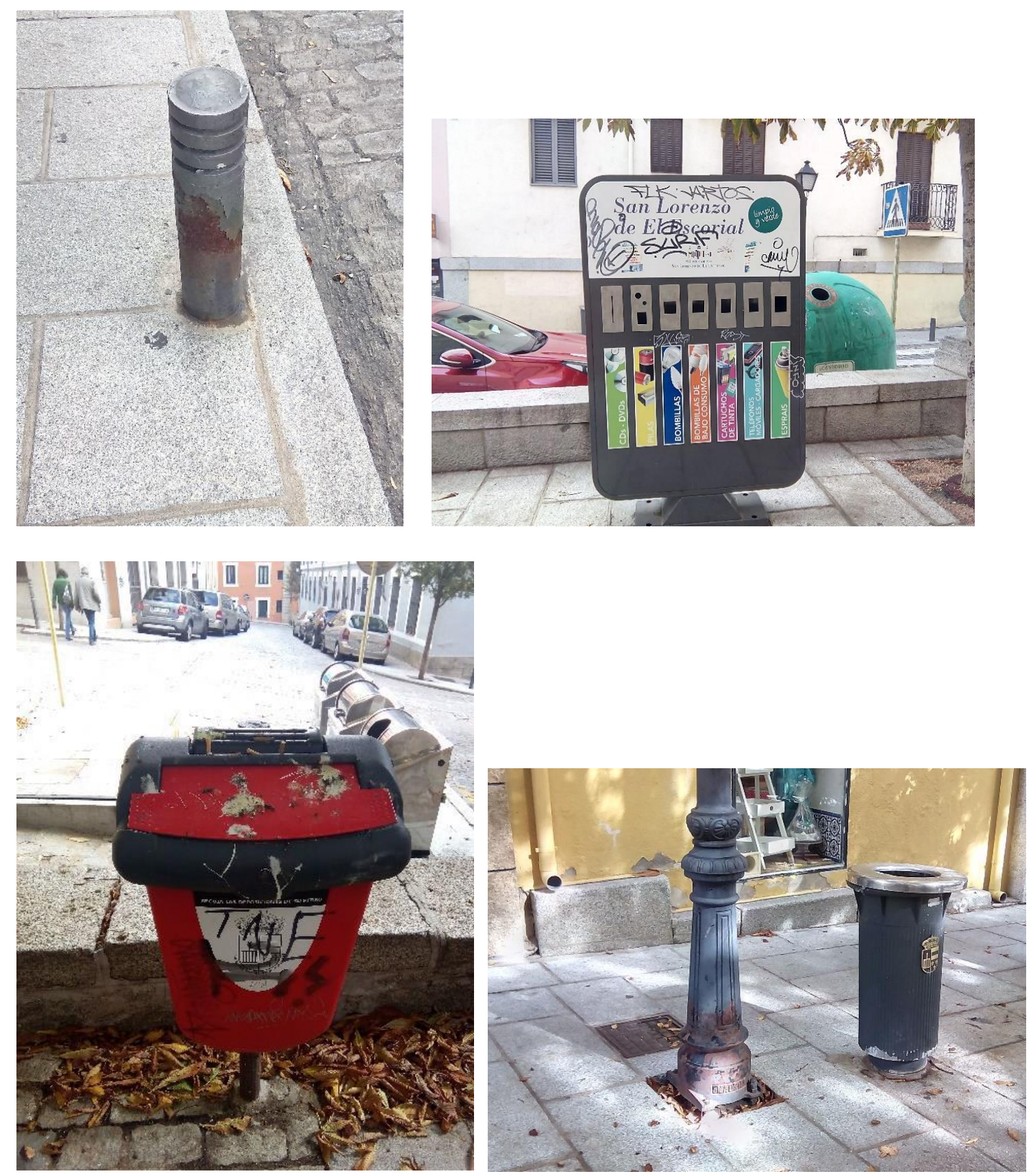
(C) Mario Martín Merino, 2021
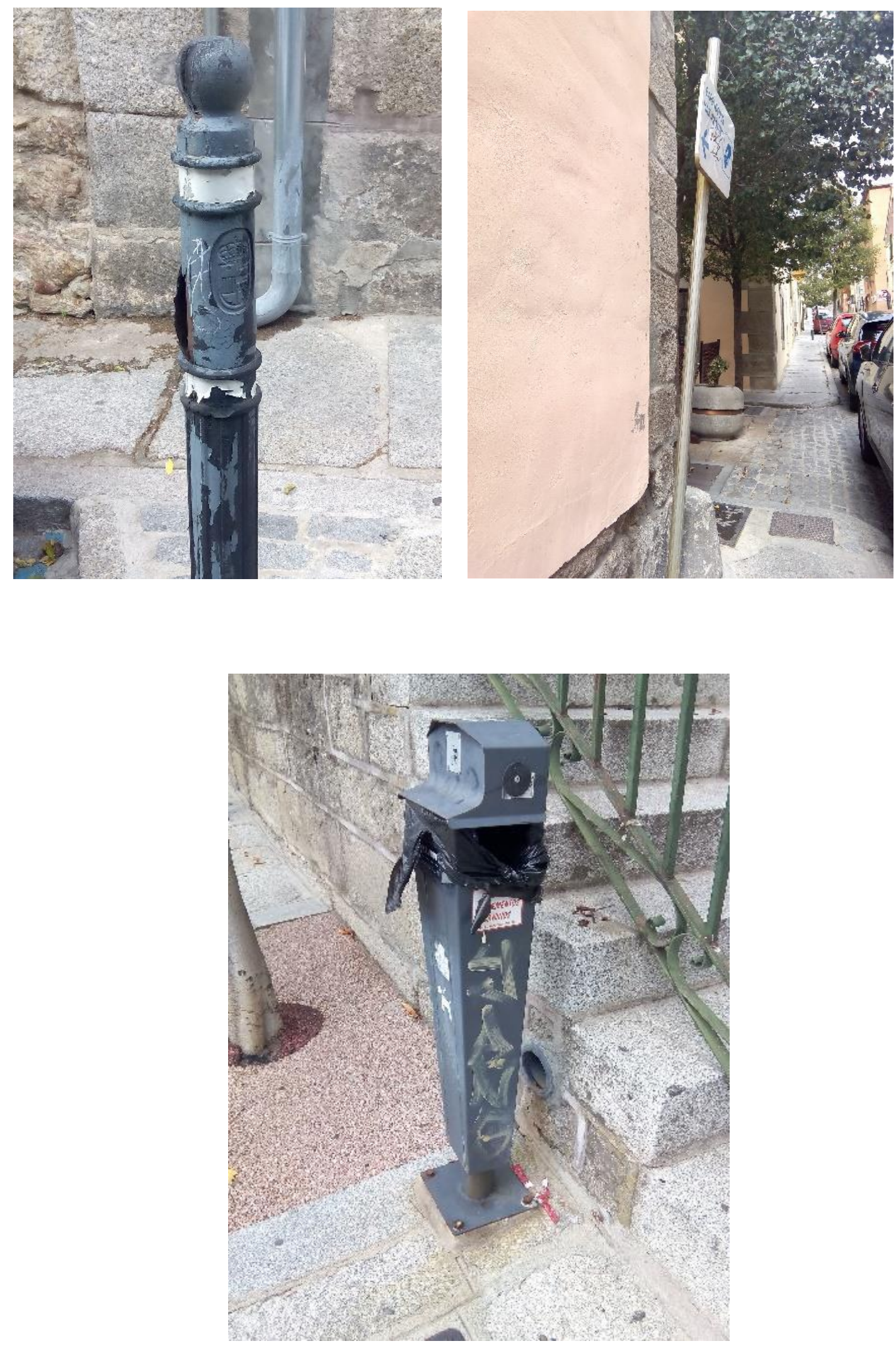
(C) Mario Martín Merino, 2021

\section{E. Plaza de la Constitución}
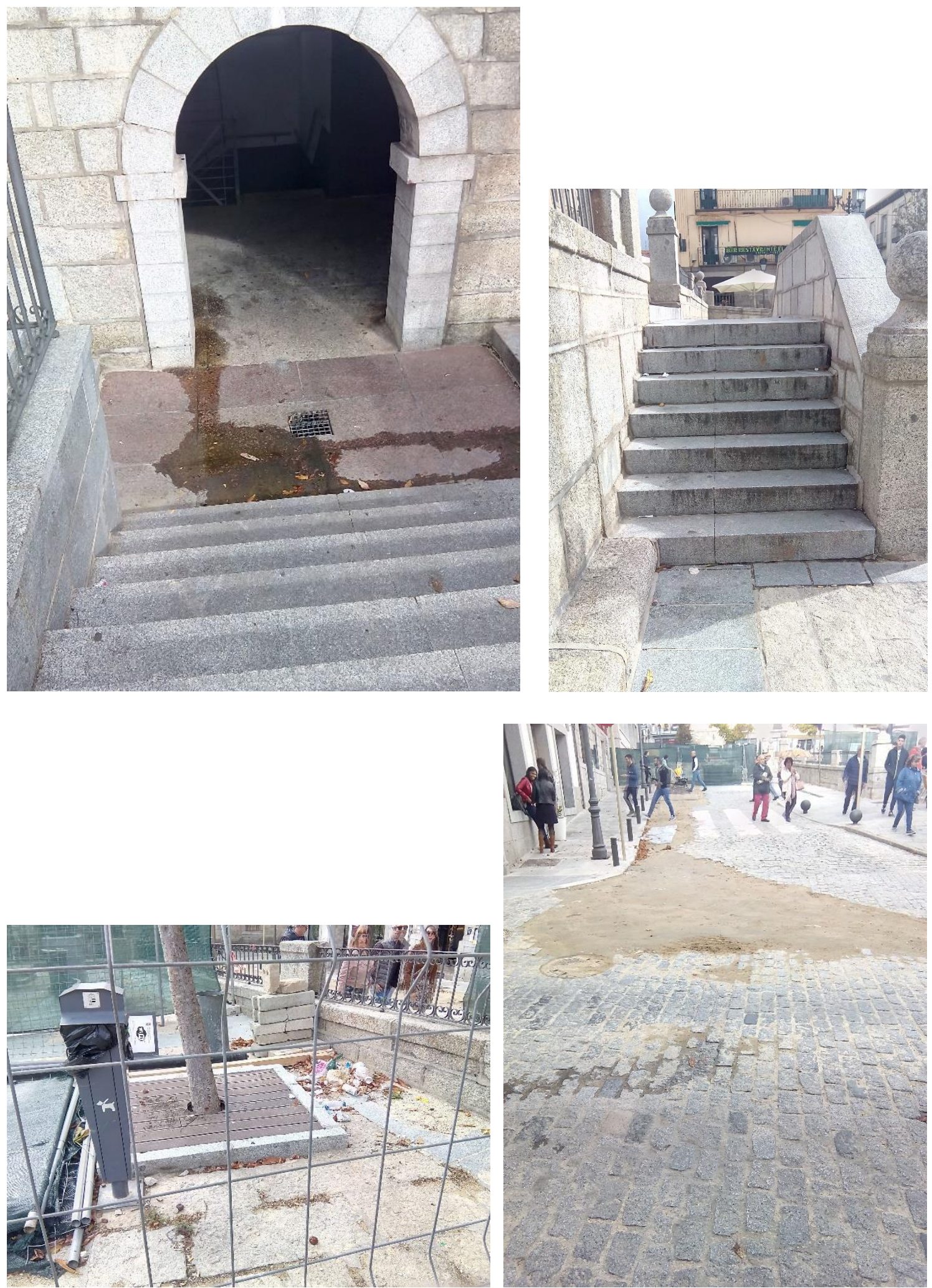
(C) Mario Martín Merino, 2021

\section{F. Reina Victoria Street}
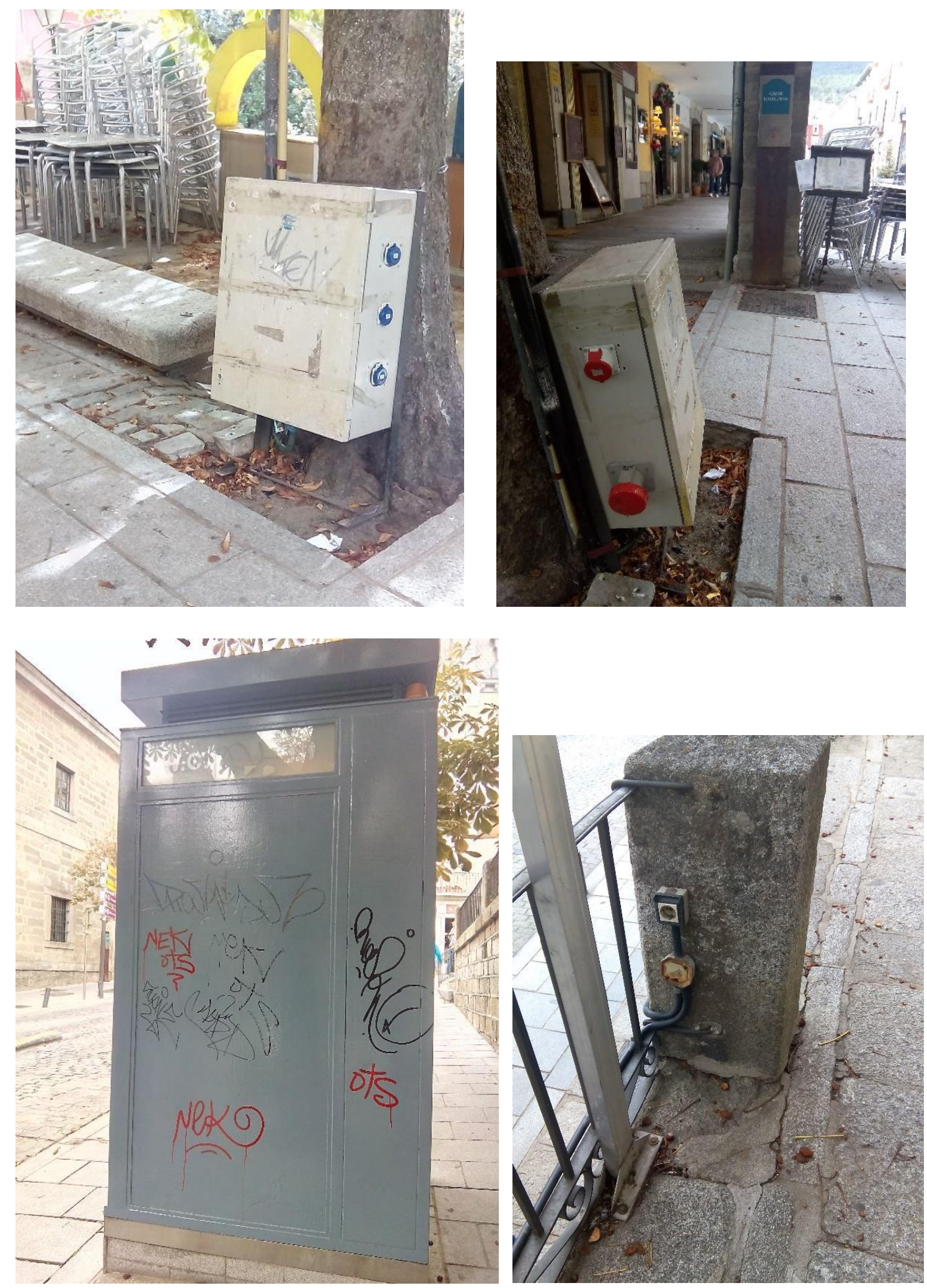
(C) Mario Martín Merino, 2021

G. Cleaning and maintenance of the streets
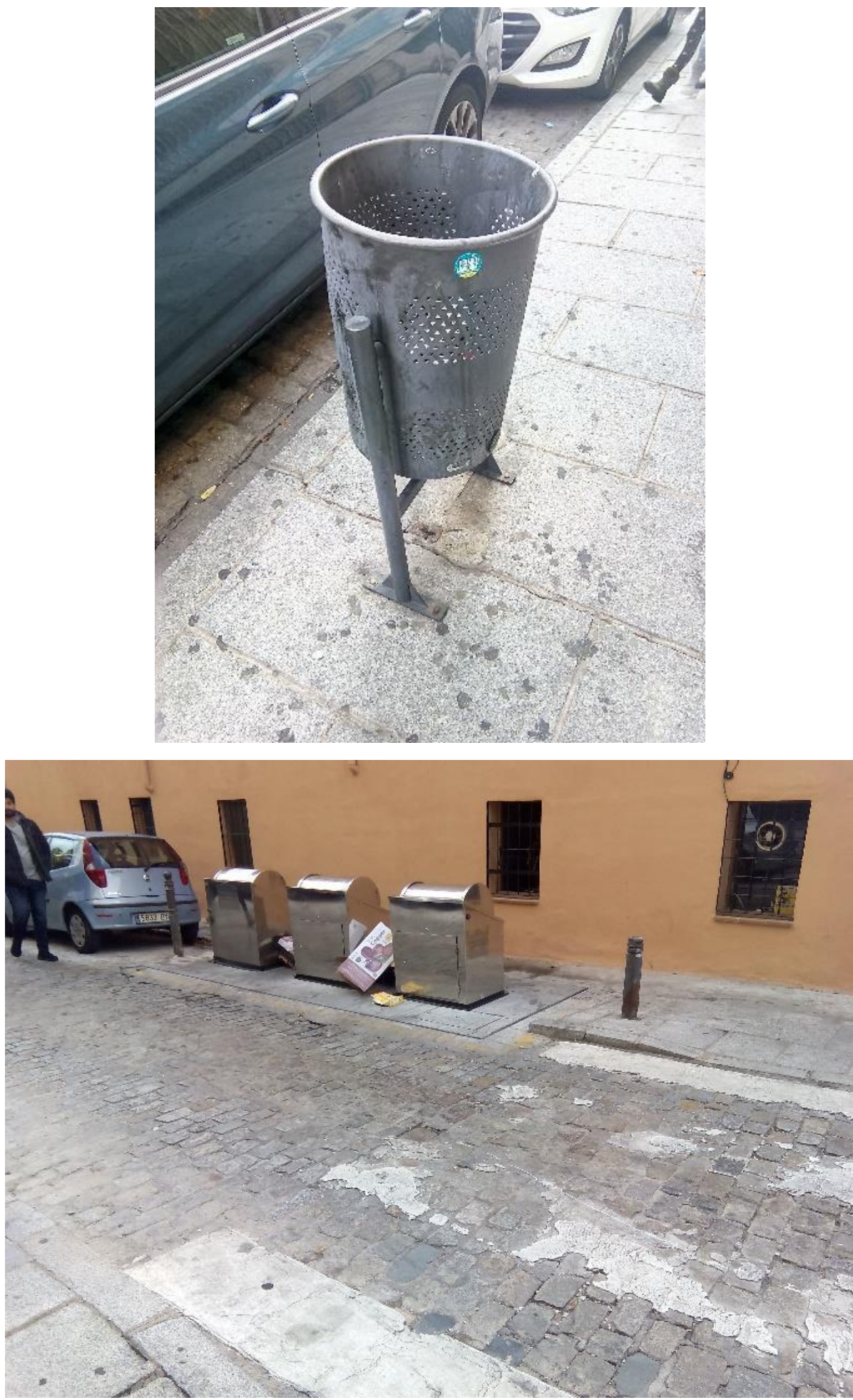
(C) Mario Martín Merino, 2021
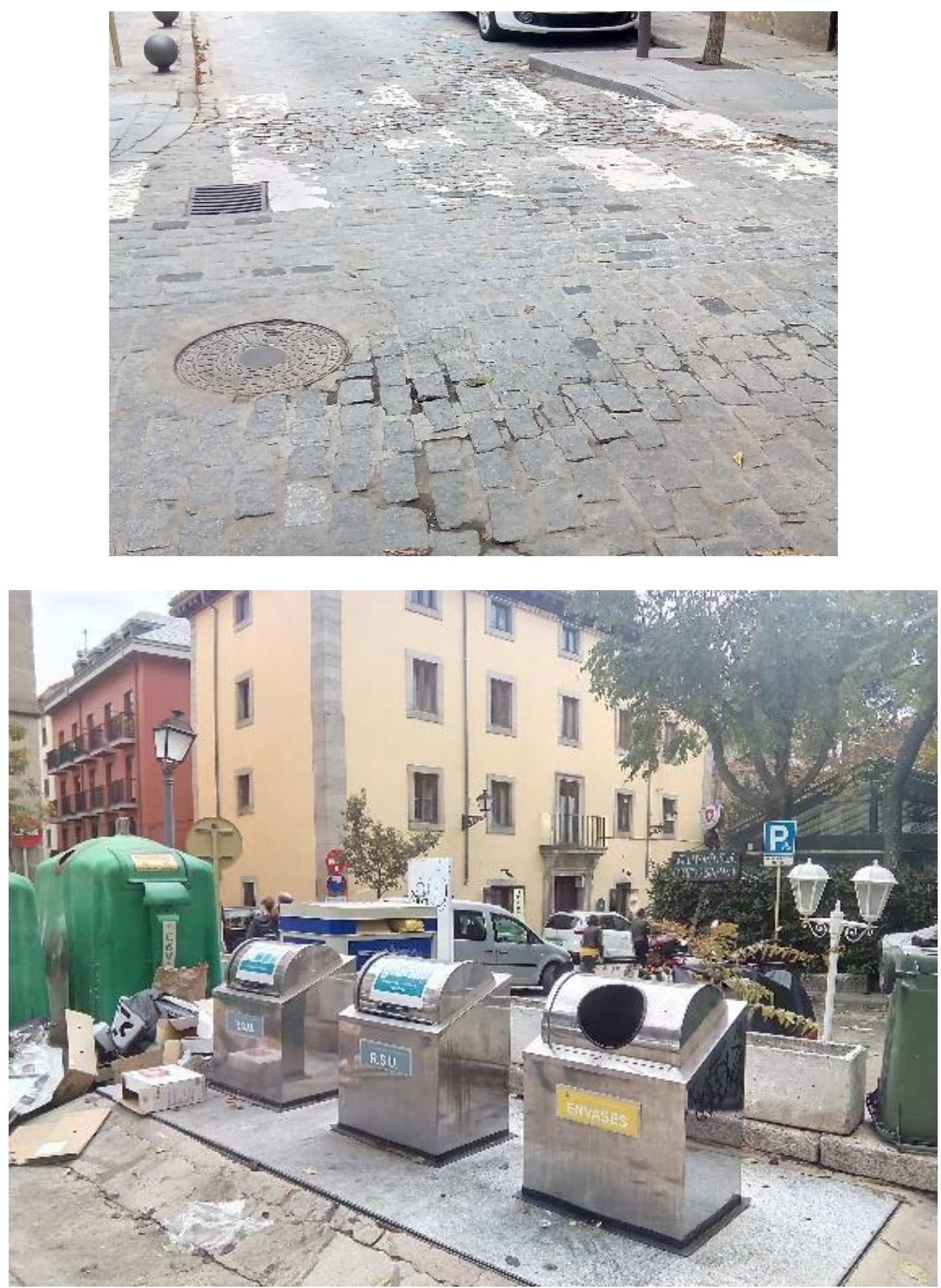
(C) Mario Martín Merino, 2021
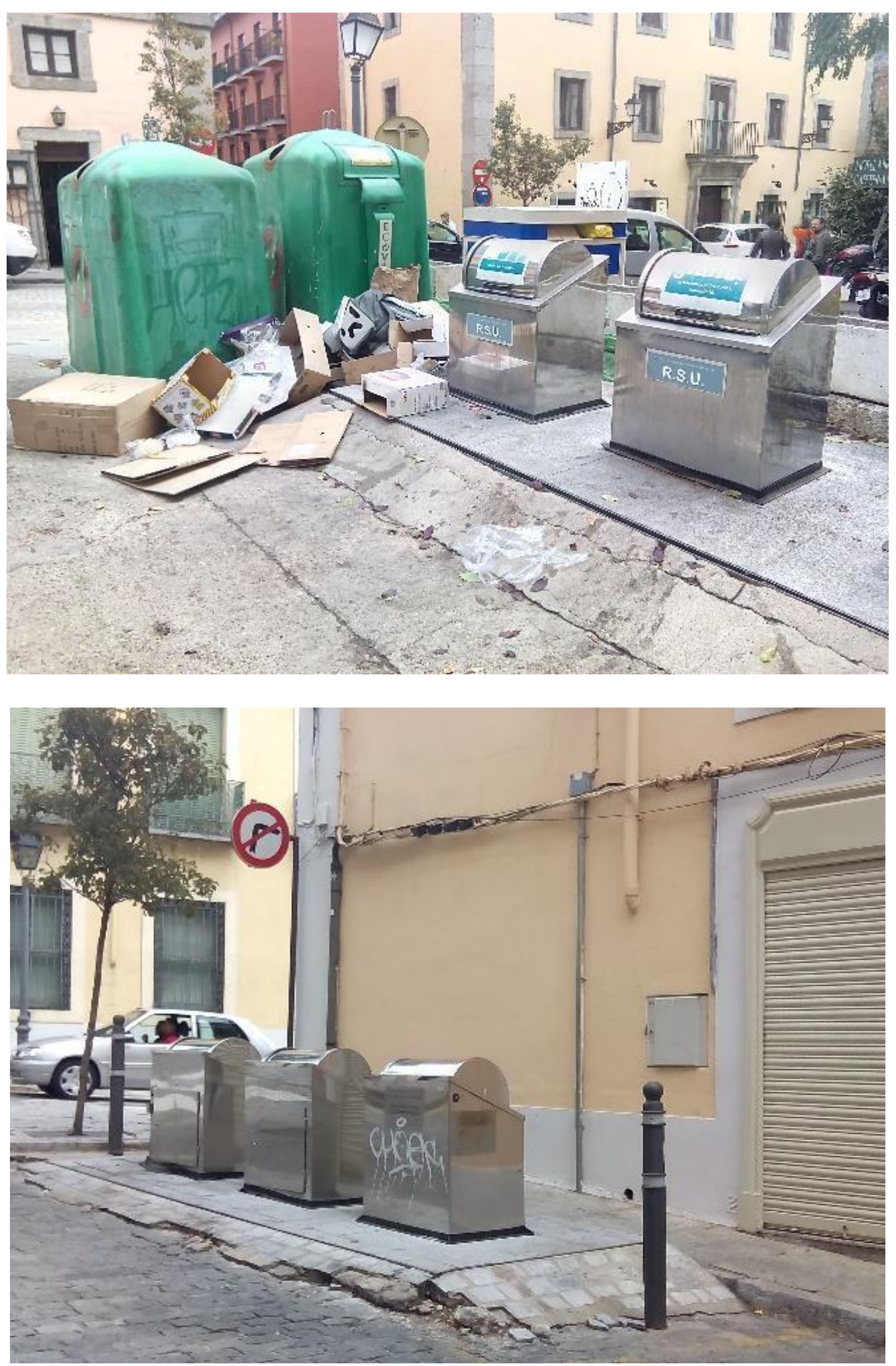
(C) Mario Martín Merino, 2021
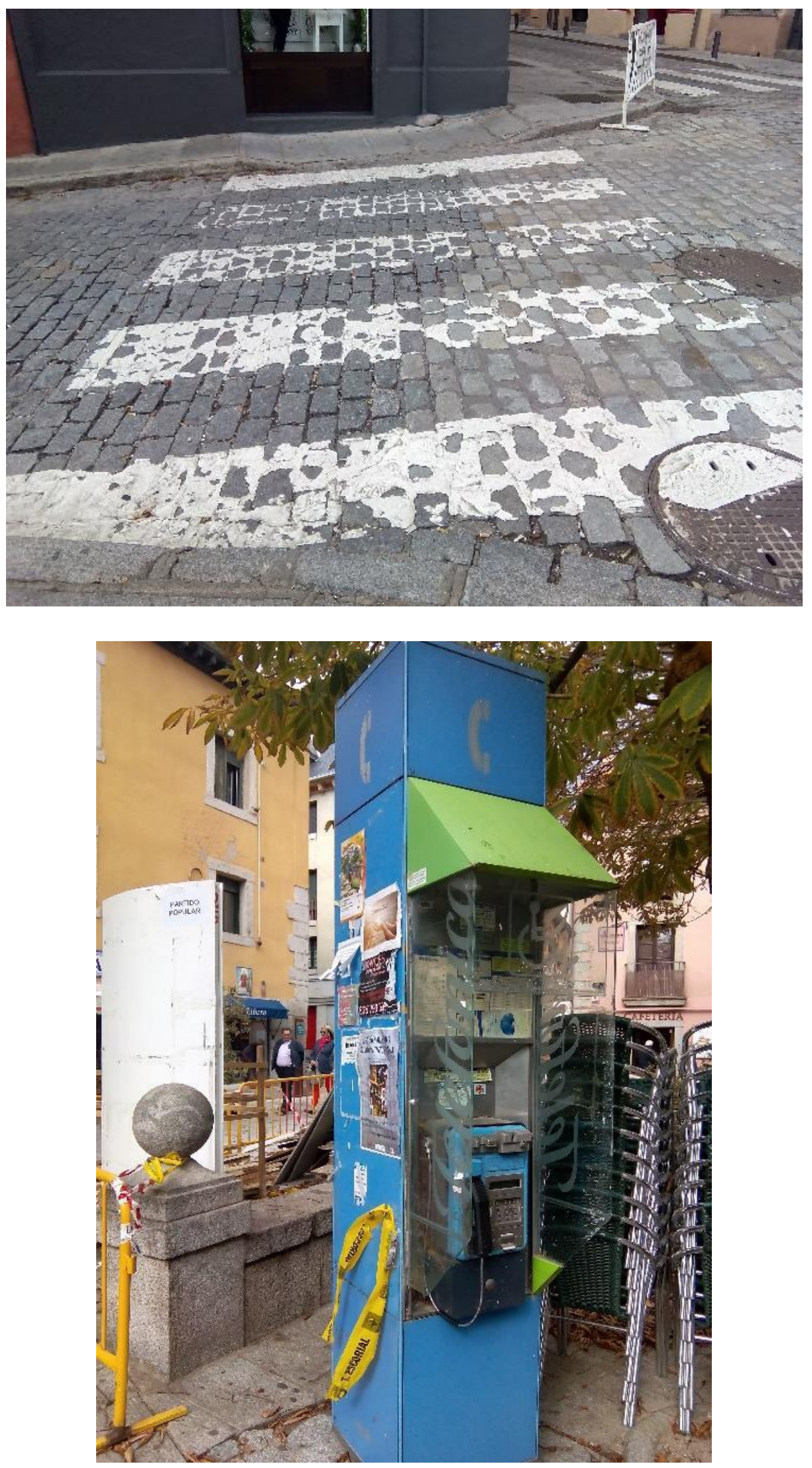

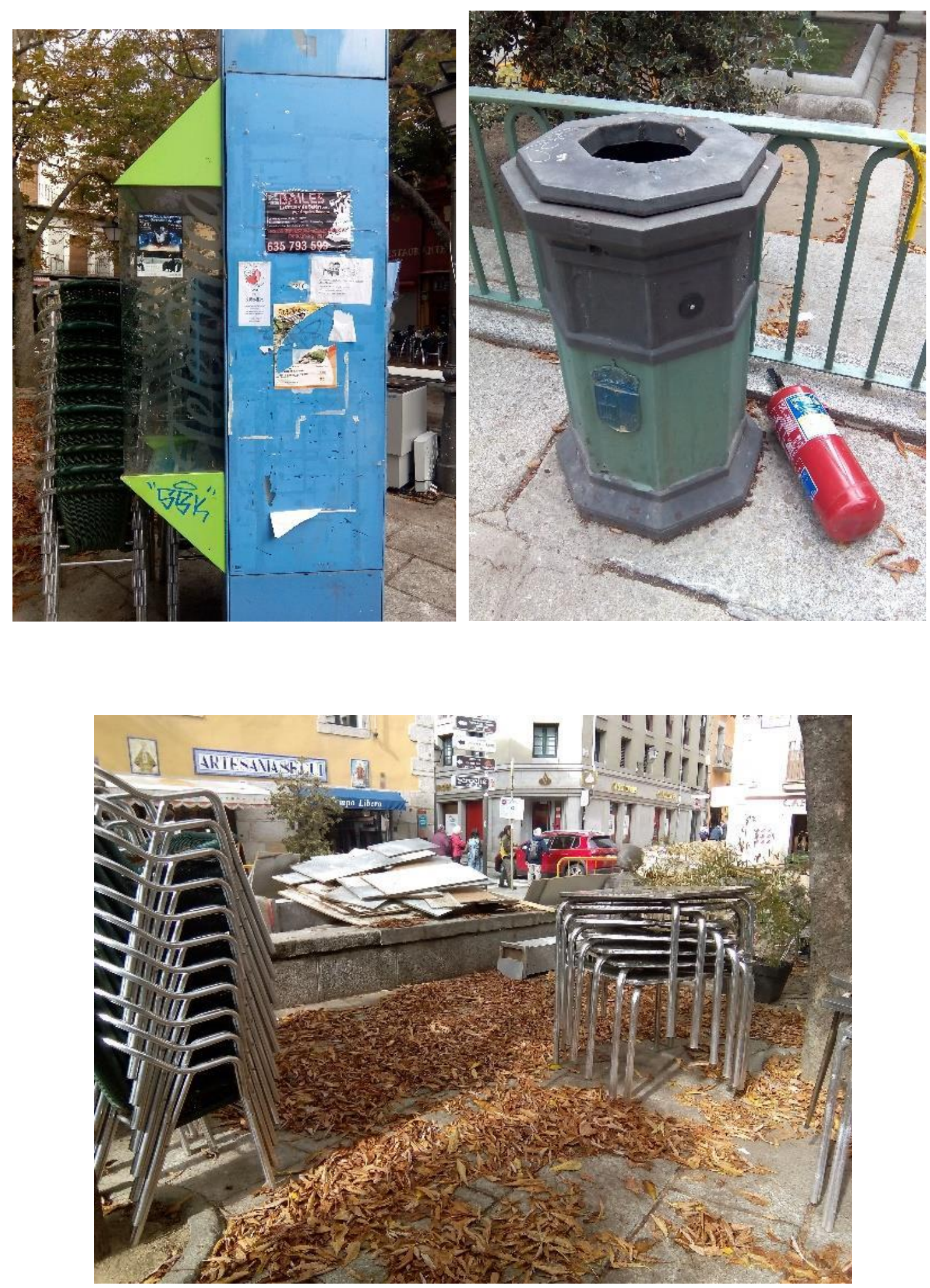


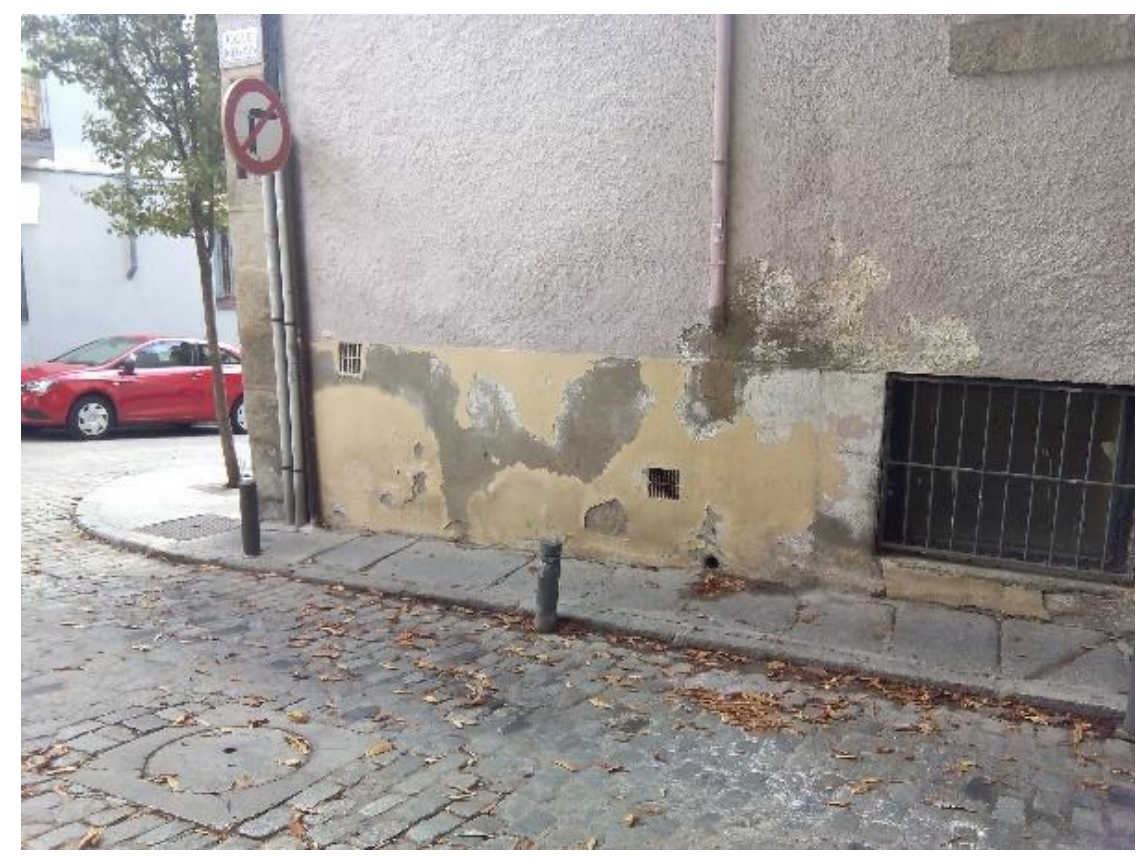

H. Badly parked vehicles and entrance to the parking lot of the Plaza de la Constitución

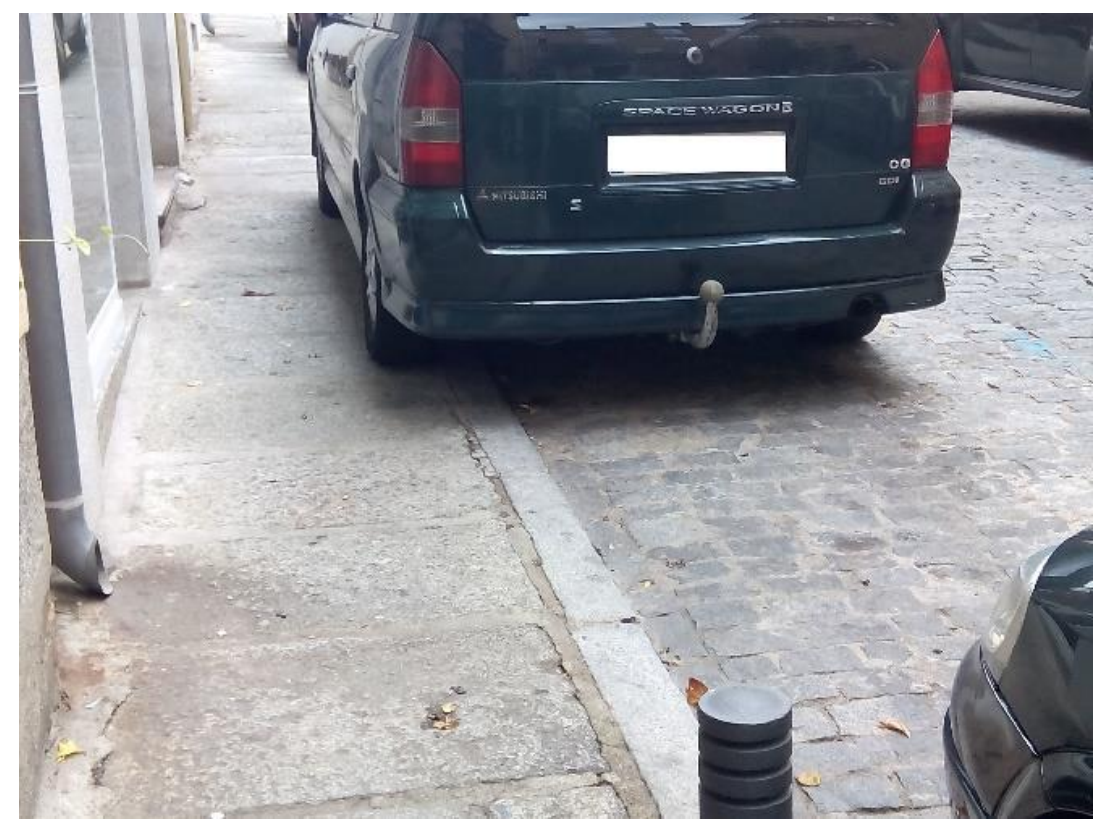


(C) Mario Martín Merino, 2021
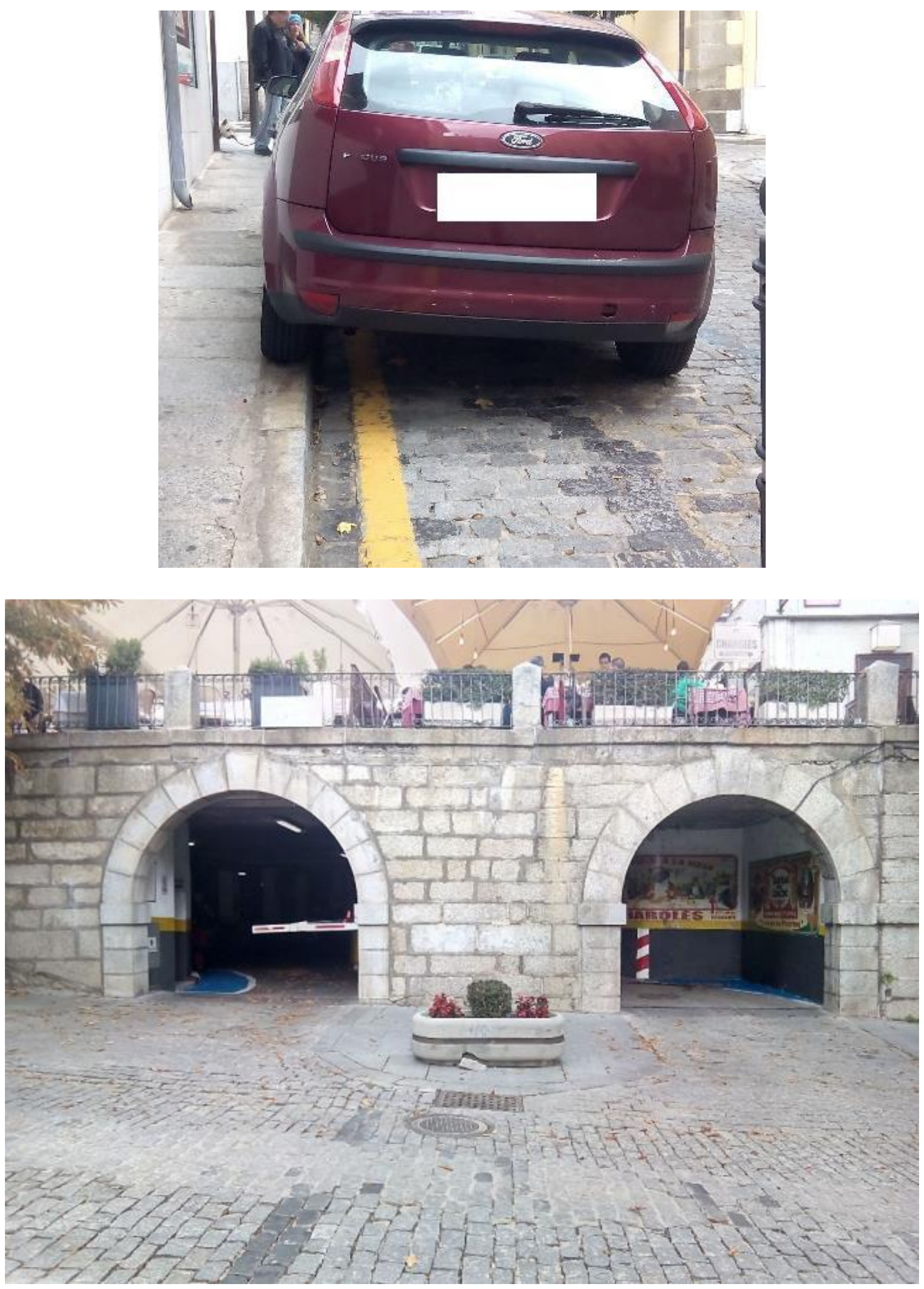